\title{
MODELO EMPÍRICO DE DEPRECIAÇÃO PARA TRATORES AGRÍCOLAS DE RODAS
}

\author{
Rui MARcos Assis Cosentino
}

Dissertação apresentada à Escola Superior de Agricultura

"Luiz de Queiroz", Universidade de São Paulo, para obtenção do titulo de mestre em Agronomia Área de Concentração: Máquinas Agrícolas.

\author{
P I R A C I C A B A \\ Estado de São Paulo - Brasil \\ Outubro - 2004
}




\title{
MODELO EMPÍRICO DE DEPRECIAÇÃO PARA TRATORES AGRÍCOLAS DE RODAS
}

\section{RUi Marcos Assis Cosentino}

Administrador de Empresas

Orientador: Prof. Dr. MARCOS MILAN

Dissertação apresentada à Escola Superior de Agricultura

"Luiz de Queiroz", Universidade de São Paulo, para obtenção do titulo de mestre em Agronomia Área de Concentração: Máquinas Agrícolas.

\author{
P I R A C I C A B A \\ Estado de São Paulo - Brasil
}

Outubro - 2004 


\section{Dados Internacionais de Catalogação na Publicação (CIP) DIVISÃO DE BIBLIOTECA E DOCUMENTAÇÃO - ESALQ/USP}

\section{Cosentino, Rui Marcos Assis}

Modelo empírico de depreciação para tratores agrícolas de rodas / Rui Marcos Assis

Cosentino. - - Piracicaba, 2004.

80 p. : il.

Dissertação (Mestrado) - - Escola Superior de Agricultura Luiz de Queiroz, 2004.

Bibliografia.

1. Análise de regressão 2. Depreciação econômica 3. Indústria 4. Mecanização agrícola Mercado agrícola 6. Preço agrícola 7. Trator agrícola - Conservação I. Título

CDD 631.372

\section{"Permitida a cópia total ou parcial deste documento, desde que citada a fonte - O autor"}




\section{AGRADECIMENTOS}

A Deus, por me auxiliar na conclusão de uma importante etapa da minha vida.

Aos Prof. Dr. Luiz Geraldo Mialhe e Prof. Dr. Iran José Oliveira pela oportunidade e encaminhamento.

Ao Prof. Dr. Marcos Milan pelo acolhimento, orientação irrepreensível, amizade e principalmente pela paciência em todo processo.

A Profa. Dra. Sonia Maria de Stefano Piedade pela atenção e prontidão.

Aos professores do Departamento de Engenharia Rural, na pessoa do Prof. Dr. Casimiro Gadanha Dias Júnior, coordenador do Programa de Pós Graduação em Máquinas Agrícolas pela convivência.

Ao CNPq pelo apoio financeiro.

Aos funcionários do Departamento de Engenharia Rural, nas pessoas de Fernanda Barbosa, Davilmar Colevatti e D. Lurdes Franzini pela convivência e camaradagem.

A Andrés de La Reyes do CIAGRI - USP pelo apoio na obtenção de dados.

Aos amigos Martha de Toledo Piza, Marcos Silveira Bueloni, Cássia Lordelo Chaim Menezes, César Nunes Castro por fazerem parte da minha vida.

Aos amigos André Luis Sacomano Pincelli, Rodrigo Vellardo Guimarães, Thiago Libório Romanelli pelo apoio e incentivo a esse trabalho.

Aos amigos Gustavo Nagumo, Gustavo Fontana, Gustavo Faulin, Saulo Salaber, Murilo Suguisawa, Fabiana Franco, Flavio Cabrera, Ney Sidou, Rodrigo Bonato, Adriano Barbosa, Jose Vitor Salvi, Rapahael Magalhães, Paulo Bettini, Paulo César Silva, Leonardo Mascarim, Wladimir Camargo, Allison de Oliveira pela convivência durante a realização do curso. 
“Combati o bom combate, acabei a carreira, guardei a fé”.

(2Tm 7:7)

Á minha esposa Juliana que, com seu jeito especial e paciência, contribuiu muito para que pudesse realizar tanto este como outros projetos em minha vida,

aos meus pais Diná e Ruy, pelo apoio,

aos meus irmãos Sonia, Alexandre e Thaís, que me ajudaram nos momentos críticos cada qual da sua maneira,

aos meus afilhados Vinicius, Vitor e Vitor e as afilhadas do coração Larissa e Letícia,

dedico este trabalho e, mais do que tudo meu amor. 


\section{SUMÁRIO}

Página

LISTA DE FIGURAS................................................................................. vii

LISTA DE TABELAS.......................................................................... ix

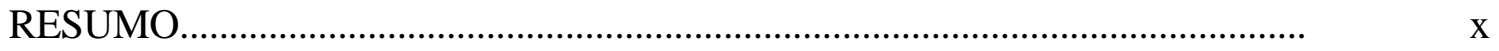

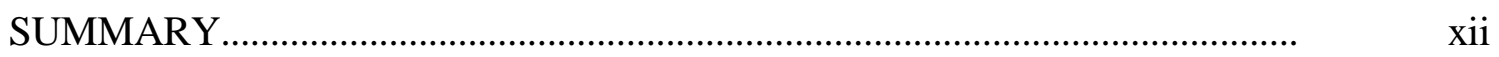

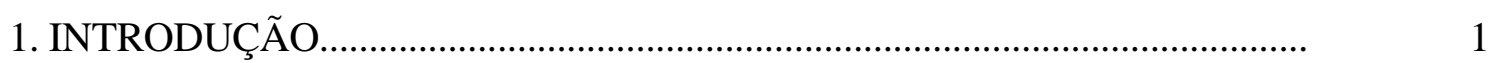

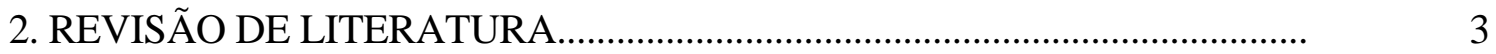

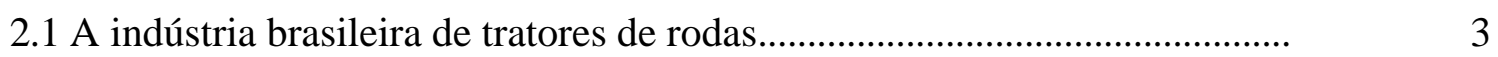

2.2 A frota brasileira e o índice de mecanização......................................................

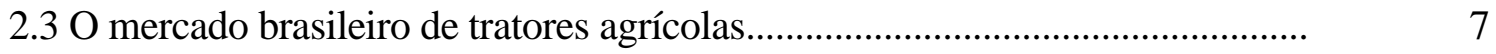

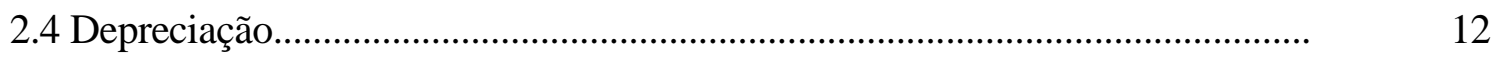

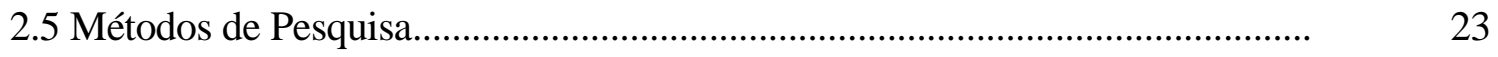

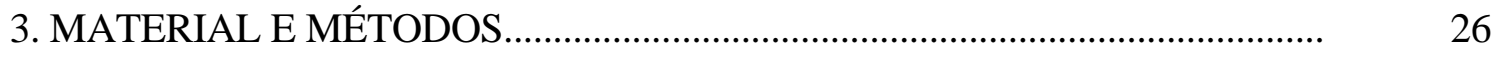

3.1 Levantamento de preço de tratores usados......................................................... 26

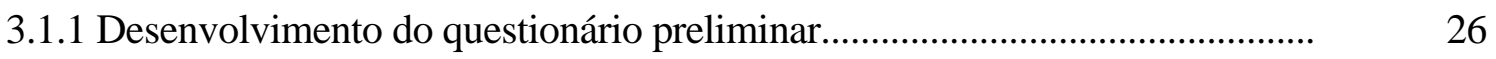

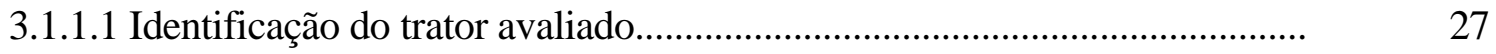

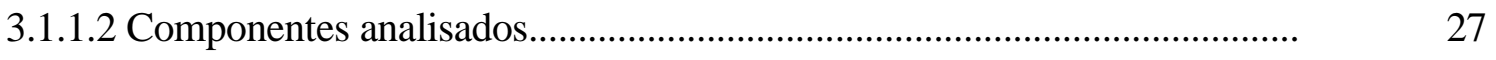

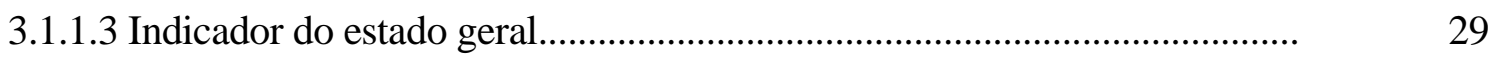

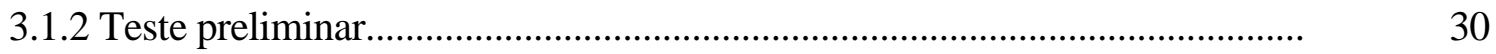

3.1.3 Questionário definitivo............................................................................ 30

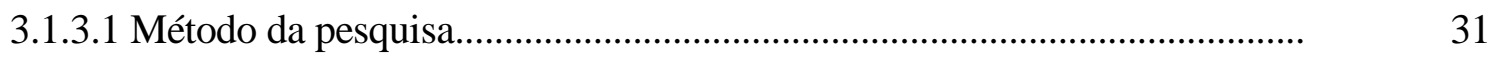

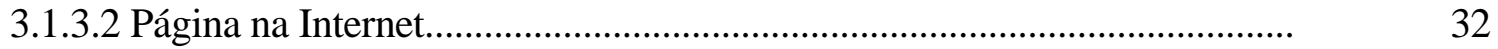

3.2 Obtenção do valor inicial............................................................................... 32

3.2.1 O valor do trator no O Estado de São Paulo....................................................... 


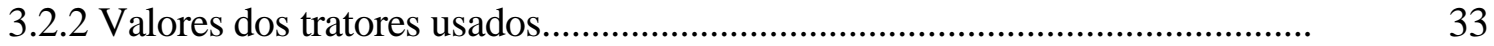

3.3 Tratamento e análise dos dados.......................................................................... 36

3.4 Modelos adotados para comparação....................................................................

3.4.1 Método da linha reta ou linear...........................................................................

3.4.2 Método saldo decrescente...............................................................................

3.4.3 Método soma dos dígitos dos anos................................................................... 38

3.4.4 Método do fundo de recuperação de capital........................................................ 39

3.4.5 Valores dos tratores usados com base no Estado de São Paulo.......................... 39

4 RESULTADOS E DISCUSSÃO.........................................................................

4.1 Questionário....................................................................................................

4.2 Análise descritiva dos resultados....................................................................... 42

4.2.1 Faixa de potência..............................................................................................

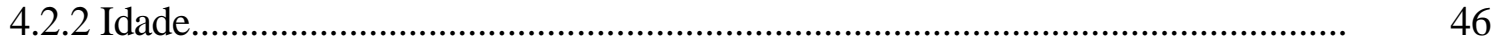

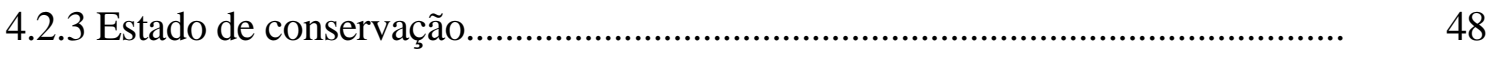

4.2.4 Horas trabalhadas........................................................................................... 51

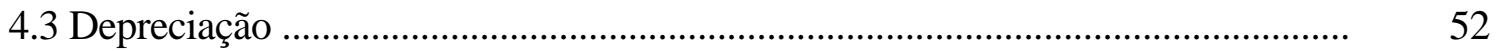

4.3.1 Análise ..........................................................................................................

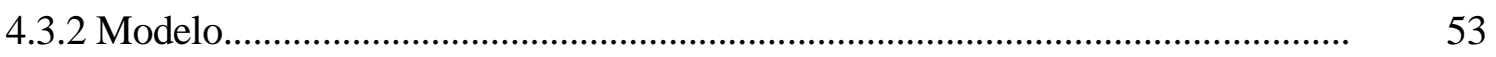

4.4 Comparação com os modelos propostos................................................................ 54

5 CONCLUSÕES.........................................................................................

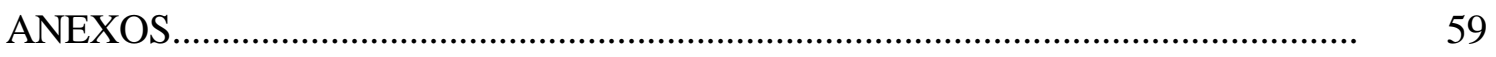

REFERÊNCIAS BIBLIOGRÁFICAS...................................................................... 


\section{LISTA DE FIGURAS}

Página

1 Comportamento das vendas anuais de tratores agrícolas de rodas

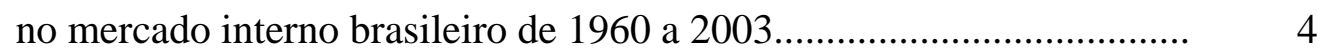

2 Índice de mecanização, área cultivada por ano.................................. 6

3 Participação em vendas ao mercado interno por empresa no ano 2003.... 7

4 Distribuição das vendas e rede de distribuidores por região 2002........... 8

5 Distribuição de vendas de tratores agrícolas por faixa de potência e marca

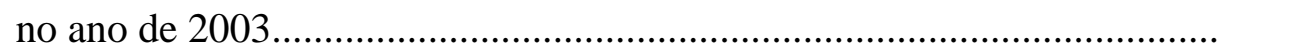

6 Inter-relação entre fatores que definem uma pesquisa, adaptado de Richardson et al (1995)....................................................................... 23

7 Secção do questionário que descrimina o grupo motor...................... 40

8 Distribuição percentual de tratores de $37.80 \mathrm{~kW}$ a $74.84 \mathrm{~kW}$.................... 43

9 Potências fabricadas de 75.60 kW a 150.44 kW ...................................... 45 
10 Idade dos tratores coletados..............................................................

11 Estado de conservação avaliado nos tratores com idade de 0 a 5 anos

12 Estado de conservação avaliado nos tratores com idade de 5 até 10 anos

13 Estado de conservação de tratores com mais 10 anos.

14 Modelo determinado para depreciação de tratores agrícolas com mais de um ano de uso.............................................................

15. Comparação com valores em reais de um trator de Massey Ferguson MF 680 de 130,78 kW sem cabine...................................................... 


\section{LISTA DE TABELAS}

Página

1. Índice de mecanização da agricultura mundial................................ 7

2. Vendas anuais em percentagem por faixa de potência..................... 9

3. Participação relativa dos componentes do custo total para dois modelos de tratores......................................................................

4. Estimativa de vida útil de máquinas e implementos..........................

5. Descrição da Fontes de dados

6. Cidade e estado dos revendedores participantes.

7. Potência, faixa de potência, unidades.

8. Estatística descritiva das horas trabalhadas........................................

9. Análise de regressão. 


\title{
MODELO EMPÍRICO DE DEPRECIAÇÃO PARA TRATORES DE RODAS
}

\author{
Autor: RUI MARCOS ASSIS COSENTINO \\ Orientador: Prof. Dr. MARCOS MILAN
}

\section{RESUMO}

A depreciação de tratores agrícolas de rodas é um importante componente do custo fixo. A correta determinação desse parâmetro torna-se vital para o cálculo do custo da maquinaria ao longo da vida útil. Vários métodos são propostos para a estimativa da depreciação dos tratores com mais de um ano de uso: linear, saldo decrescente, soma do digíto dos anos, fundo de recuperação de capital e os valores publicados pelo jornal “O Estado de São Paulo”. O mais adequado entre os métodos disponíveis é o preço de mercado, que está baseado na pesquisa do valor da maquinaria junto ao mercado. Este trabalho consiste, em uma pesquisa para o levantamento, no mercado, de preços de venda de tratores agrícolas de rodas usados e na comparação dos valores obtidos (valor real de mercado) com os propostos na bibliografia. Para obtenção dos preços de mercado foi elaborado um questionário contendo as informações sobre o exemplar avaliado e os principais componentes de um trator agrícola, a fim de avaliar o estado de conservação do trator, indicando notas de 1 (ruim) a 5 (ótimo), conforme o estado dos componentes . O questionário foi disponibilizado no site da Escola Superior de Agricultura “Luiz de Queiroz” ESALQ-USP, tendo sido enviado a concessionários de todo país um pedido para que participassem da pesquisa. $\mathrm{O}$ baixo índice de respostas, cerca de 3\%, motivou uma pesquisa feita junto a concessionários num raio de $150 \mathrm{~km}$ da cidade de Piracicaba. A etapa posterior à coleta foi a análise da vida útil (em anos), potência, horas trabalhada e o estado de conservação dos tratores avaliados. Com o avanço da idade do trator o estado de conservação ia se deteriorando, tendo sido encontrados tratores com até 34 anos de vida útil. A análise das horas trabalhadas foi prejudicada pela falta de confiabilidade nos horímetros e nas informações coletadas em tratores com instrumentos danificados. Potências encontradas na frota avaliada foram concentradas nas com maior índice de comercialização no país. A análise de regressão foi significativa somente em relação à vida útil e preço de mercado. A comparação entre o modelo obtido e os métodos 
propostos revelou uma diferença expressiva no primeiro ano, sendo que o modelo empírico demonstrou-se preciso: a partir do sétimo ano, em comparação com o método linear e o saldo decrescente; a partir do terceiro ano, em relação á soma dos dígitos dos anos e os valores publicados em "O Estado de São Paulo"; e a partir do oitavo ano, em comparação com o método fundo de recuperação de capital. 


\title{
EMPIRICAL MODEL OF DEPRECIATION FOR TRACTORS OF WHEELS
}

\author{
Author: RUI MARCOS ASSIS COSENTINO
}

Adviser: Prof. Dr. MARCOS MILAN

\section{SUMMARY}

The depreciation of wheeled tractors is an important component of the fixed cost. The right determination of this parameter is vital to determine the machinery cost during its useful life. Several methods are proposed in order to estimate tractor depreciation with more than a year of use: linear, decreasing balance, sum of the year's digit, fund of capital recovery and the values published by the newspaper " $\mathrm{O}$ Estado de São Paulo". The most adequate among the available methods is the market price, which is based on research of the machinery value ok tractor dealers. This work consists in a surveying of sale prices of agricultural wheeled tractors and in the comparison of the obtained data (value practiced in the market) with those obtained by methods proposed on references. In order to obtain these data it was elaborated a questionnaire, which had fields for the evaluated machine and its main components to be evaluated. For the evaluation of the tractor conservation, grades from 1 (bad) to 5 (excellent) were attributed to each component. This questionnaire was available on the web site of the College of Agriculture "Luiz de Queiroz", University of São Paulo. Tractor dealers throughout the country were contacted and asked to join the survey. The low rate of answers (3\%) motivated a survey done directly to dealers located in a 150$\mathrm{km}$ radius from Piracicaba, state of São Paulo. The step after the data collection was the analyses of useful life (years), power, worked hours and the conservation state of the evaluated tractors. As the tractor age was increasing the conservation state was worsening. Tractors up to 34 years of use were counted. The analysis of worked hours was hardened by the lack of trustfulness of the hour counter and by the information gotten in tractors with broken instruments. Power levels found in the evaluated fleet were concentrated on those more traded in Brazil. The regression analysis was significant only when useful life and market price were related. The comparison between the developed model and the proposed methods revealed the biggest difference on the 
first year of use, and it became more trustful from the seventh year of use, comparing with the linear and decreasing balance methods; when comparing to the sum of the year's digit method and the values published by the newspaper "O Estado de São Paulo", from the third year of use, and finally, when comparing to fund of capital recovery method, from the eighth year of use. 


\section{INTRODUÇÃO}

A agricultura é uma atividade que nos últimos anos tem sido um importante componente da economia do Brasil, representando quase $6 \%$ do PIB no ano de 2003, de acordo com o IBGE, foi o único setor do país com crescimento efetivo no ano.

As culturas como a soja, milho, laranja e café têm conquistado um espaço cada vez maior no mercado internacional, a ponto de preocupar outros países produtores. Essa inserção no mercado internacional se deu por meio de aumento da produtividade e preços competitivos. Resultados significativos como esse mostram ser cada vez mais necessária a aplicação da maquinaria para executar operações agrícolas, algumas como a colheita de cana, de algodão e soja, são totalmente mecanizadas.

A atividade agrícola é cada vez mais associada a tecnologia aplicada a maquinaria tanto para o aumento da produção como para redução de custos. Diante isto, há necessidade de se gerenciar os custos da atividade agrícola. As decisões a serem tomadas para a racionalização econômica da máquina agrícola tornam-se cada vez mais difíceis, a maquinaria representa um significativo investimento na produção agrícola, reduzindo sua importância somente frente à propriedade da terra (Cross \& Perry, 1995).

O cálculo do custo operacional ao longo da vida útil torna-se fundamental para o uso racional do trator agrícola. Para a determinação do custo operacional deve-se calcular o custo horário total, que depende da estimativa dos custos fixo e variável. Na estimativa do custo fixo a depreciação é um dos componentes mais importantes.

No Brasil, poucos trabalhos tratam do assunto, ainda que existam modelos para a determinação do custo de depreciação, que podem não estar refletindo a realidade. A determinação incorreta da depreciação equivale a subestimar custos. 
Tendo em vista a importância da estimativa do custo fixo para o cálculo do custo horário das máquinas e implementos, o objetivo deste trabalho foi determinar a depreciação real dos tratores agrícolas de rodas por meio de uma pesquisa de preço junto ao mercado, e relacionar com modelos propostos na bibliografia. 


\section{REVISÃO DE LITERATURA}

\subsection{A indústria brasileira de tratores de rodas}

A Associação Nacional dos Fabricantes de Veículos Automotores (Anfavea), reúne empresas fabricantes de autoveículos (automóveis, comerciais leves, caminhões, ônibus) e máquinas agrícolas automotrizes (tratores de rodas e de esteiras, cultivadores motorizados, colhedoras e retroescavadoras) com instalações industriais no Brasil ou em vias de iniciar a produção. A entidade acompanhou a implantação do Plano Nacional da Indústria de Tratores Agrícolas, instituído em 1959 pelo governo com o propósito de produzir internamente tratores, que até então eram importados dos mais diversos países produtores. A frota, na época, era de aproximadamente 50 mil tratores, compreendendo 143 marcas, segundo Mialhe (1974). A implantação da indústria de tratores no Brasil não se fez acompanhar de um programa de mecanização da agricultura, o objetivo era introduzir esse segmento industrial no país; que, devido á extensão territorial, era considerado como um mercado potencial para máquinas agrícolas.

Após a implantação da indústria, as vendas no mercado nacional têm se caracterizado por altos e baixos, (Figura 1). Segundo Silva (1990) a estimativa para o período 1960-1965 era a de que o mercado absorvesse de 12000 a 30000 tratores, fato que não aconteceu.

Para o período de 1968-1975, as expectativas de crescimento da mecanização agrícola, fizeram com que o governo e os fabricantes ampliassem a capacidade do parque industrial para produzir 100000 tratores ao ano, o que nunca se concretizou até os dias atuais. 


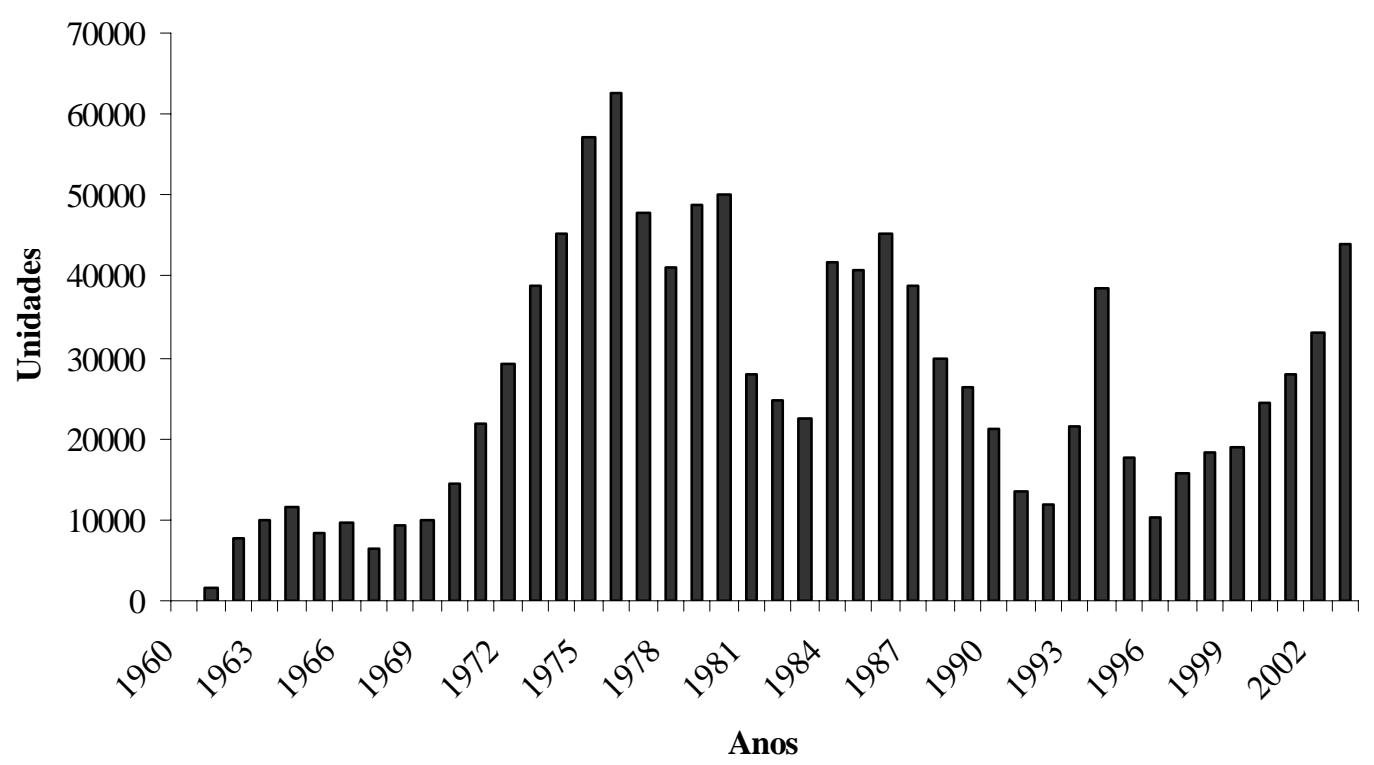

Figura 1 - Comportamento das vendas anuais de tratores agrícolas de roda no mercado interno brasileiro, no período de 1960 a 2003

Fonte: Anfavea (2003)

A venda anual média, nos anos 60, foi de 8.958 tratores. Durante a década de 70, com a modernização da agropecuária e em decorrência de uma tendência mundial de uso intensivo de insumos modernos, houve um acentuado aumento nas vendas, determinado, segundo Barros (1980), pelo crédito subsidiado. Observa-se, na Figura 1, que em 1974 foram adquiridas cinco vezes mais unidades do que em 1969, passando de 9,6 mil para 45,9 mil. O ponto alto foi no ano de 1976, quando as vendas atingiram a marca de 62.700 unidades.

Nos anos 80, segundo Molin \& Milan (2002), houve uma diminuição nas vendas em função do descontrole da economia e da seqüência de planos econômicos. Barros (1985) acrescenta, ainda, que a restrição ao crédito subsidiado foi um dos principais fatores a interferir, de forma significativa, na diminuição da produção e venda, cuja queda acentuada continuou até 1992. Para Nogueira (2001), esse foi o período em que ocorreram alterações dos indexadores das dívidas passadas e aumento da inadimplência no Crédito Rural, além da implantação do Plano Collor em 1990, que 
confiscou recursos e promoveu a abertura da economia. Em 1993, apesar das dificuldades, a indústria brasileira de tratores agrícolas apresentou uma retomada do seu crescimento e, conforme Ferreira (1995), as vendas cresceram aproximadamente 80\%.

Em 1994 houve uma melhora, baseada no aquecimento da economia por interferência do Plano Real e pela criação de uma linha de crédito para financiamento de máquinas agrícolas pelo FINAME. A isso se seguiu uma nova queda acentuada, causada, segundo Nogueira (2001a), pela perda de renda do setor e resultante da elevação dos juros e do câmbio valorizado, que dificultou as exportações. Em 1996, foram vendidas quase 10,3 mil unidades, número inferior ao do ano de 1970, com 14,6 mil unidades.

Salomão (2003) fez uma análise das vendas entre 1999-2002, constatando aumento de $77 \%$ nas vendas de tratores agrícolas de rodas no mercado interno e atribuiu o incremento á implantação do Programa de Modernização da Frota de Tratores Agrícolas, Implementos Associados e Colhedeiras (conhecido como MODERFROTA) do Ministério da Agricultura, Pecuária e Abastecimento, com recursos do Banco Nacional de Desenvolvimento Econômico e Social (BNDES), e taxas de juros fixas de 8,75\% e 12\% ao ano. A importância do MODERFROTA está na quantidade de unidades vendidas no mercado interno. No ano de 2000 o programa financiou 61\% das vendas, ou seja, 14.817 dos 24.291 tratores vendidos.

\subsection{A Frota brasileira e o índice de mecanização}

Segundo a ANFAVEA (2003), a frota de tratores de rodas estava estimada em 62,7 mil em 1960, atingiu um máximo de 551 mil em 1985 e, desde então, vem decrescendo, sendo estimada em 430 mil no ano de 2001 (Tabela 1). A frota brasileira é superior á da Argentina (280 mil), mas está distante de países altamente mecanizados como Canadá (711 mil), Reino Unido (500mil), França (1,3 milhões) e Estados Unidos (4,8 milhões).

O Brasil possui 851 milhões de hectares de terra, dos quais aproximadamente 
550 milhões são agricultáveis. Apesar do bom desempenho da agricultura nos últimos anos, apenas 10\% dessas terras agricultáveis, em torno de 52 milhões, são cultivados ( IBGE, 2003 )

O índice de mecanização na agricultura pode ser determinado pela razão entre a área cultivada e a quantidade de tratores de rodas. O país evoluiu de 410 (ha/trator) em 1960 para 124 (ha/trator) em 2001 (Figura 2).

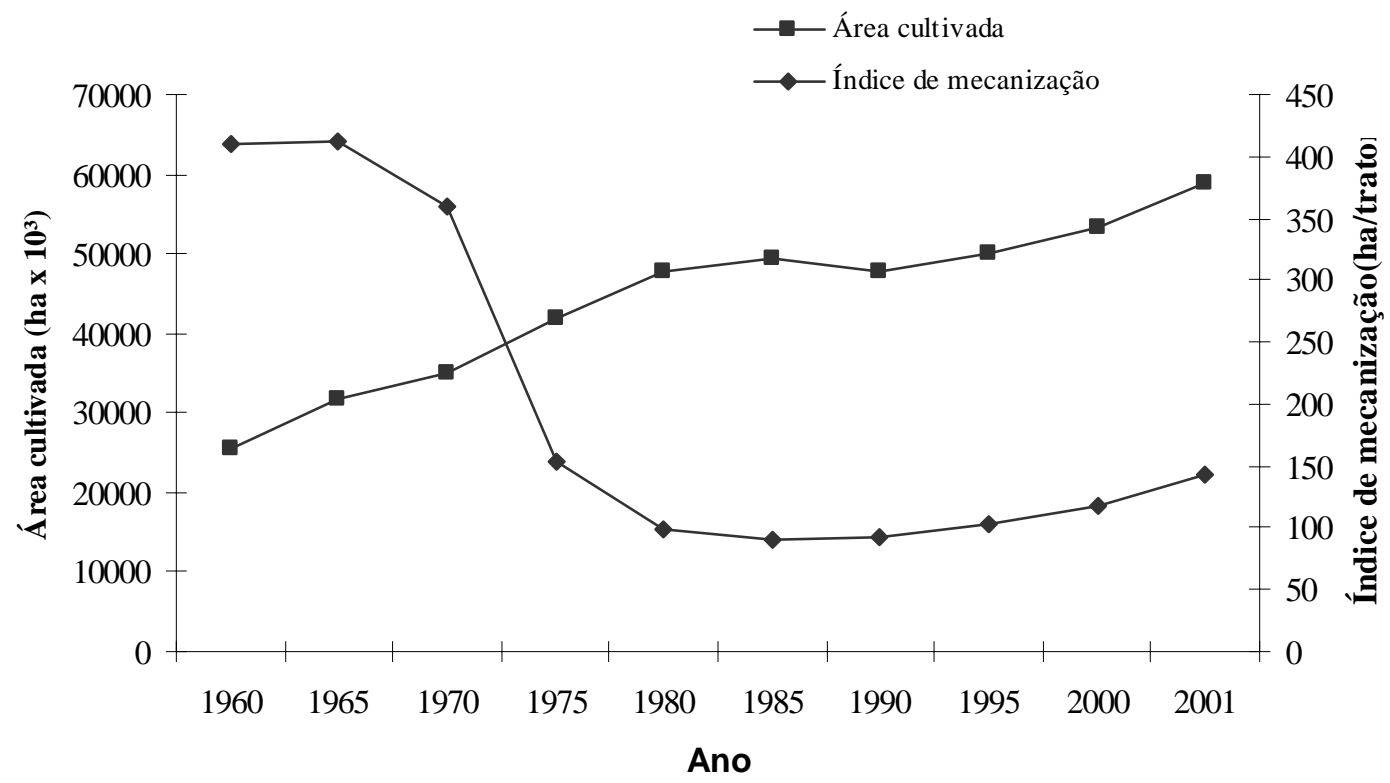

Figura 2- Índice de mecanização e área cultivada por ano Fonte: Anfavea (2003)

O índice de mecanização nacional é alto, em termos de área por trator, quando comparado com o registrado no Canadá e no Estados Unidos. Essa diferença se amplia com os números da França e do Reino Unido (ver os índices apresentados na Tabela 1). 
Tabela 1. Índice de mecanização da agricultura mundial

\begin{tabular}{lccc}
\hline País & $\begin{array}{c}\text { Frota de tratores } \\
\text { (unidades) }\end{array}$ & $\begin{array}{c}\text { Área cultivada } \\
(\mathbf{1 0 0 0} \text { ha) }\end{array}$ & $\begin{array}{c}\text { Índice de mecanização } \\
\text { (ha/trator) }\end{array}$ \\
\hline Brasil & 430.000 & 53.200 & 123,8 \\
Argentina & 280.000 & 25.000 & 89,3 \\
Canadá & 711.000 & 45.500 & 64,0 \\
EUA & 4.800 .000 & 177.000 & 36,9 \\
França & 1.264 .000 & 18.440 & 14,6 \\
Reino Unido & 500.000 & 5.876 & 11,8 \\
\hline
\end{tabular}

Fonte: Anfavea (2003)

\subsection{O mercado brasileiro de tratores agrícolas}

A indústria brasileira de tratores agrícolas que é responsável pela produção das principais máquinas e equipamentos fornecidos ao setor agrícola e dessa forma, torna-se a mais importante e maior fornecedora de bens de capital para a agricultura. O setor apresenta poucas empresas, (Figura 3): AGCO do Brasil, Agrale, Case, John Deere, New Holland (CNH) e Valtra do Brasil. Com as recentes aquisições da Case pela New Holland, da Valtra pela AGCO e da linha de tratores de rodas da Yanmar pela Agrale, o setor ficou ainda mais restrito.

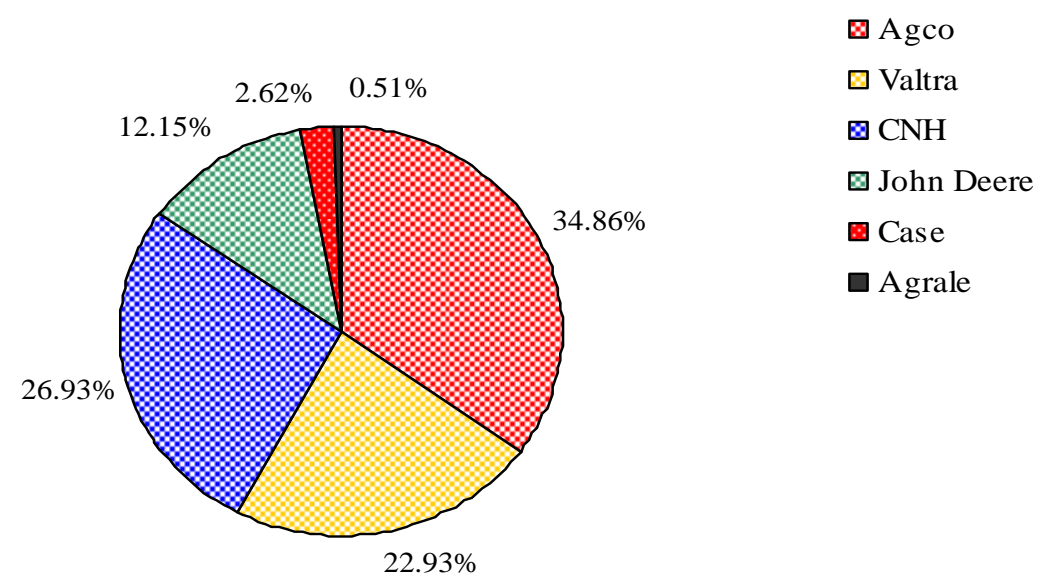

Figura 3 - Participação em vendas (\%) ao mercado interno por empresa no ano de 2003 Fonte: Anfavea (2003) 
Os fabricantes de maquinaria agrícola efetuam vendas por todo o país. A fim de representá-los regionalmente existe o revendedor, ou concessionário, cuja distribuição geográfica no território nacional pode ser observada na Figura 4.

Destaca-se a concentração de concessionários na região sul e sudeste, estando este agrupamento relacionado à proximidade com os fabricantes e com o mercado consumidor. Há apenas uma fábrica de tratores (Valtra) instalada na região sudeste desde a implantação da indústria de maquinaria agrícola no país. Na região sul estão localizadas fábricas que iniciaram a produção de tratores desde 1959, como é o caso da AGCO, Agrale, em 1965 e como John Deere (RS) e New Holland (PR).

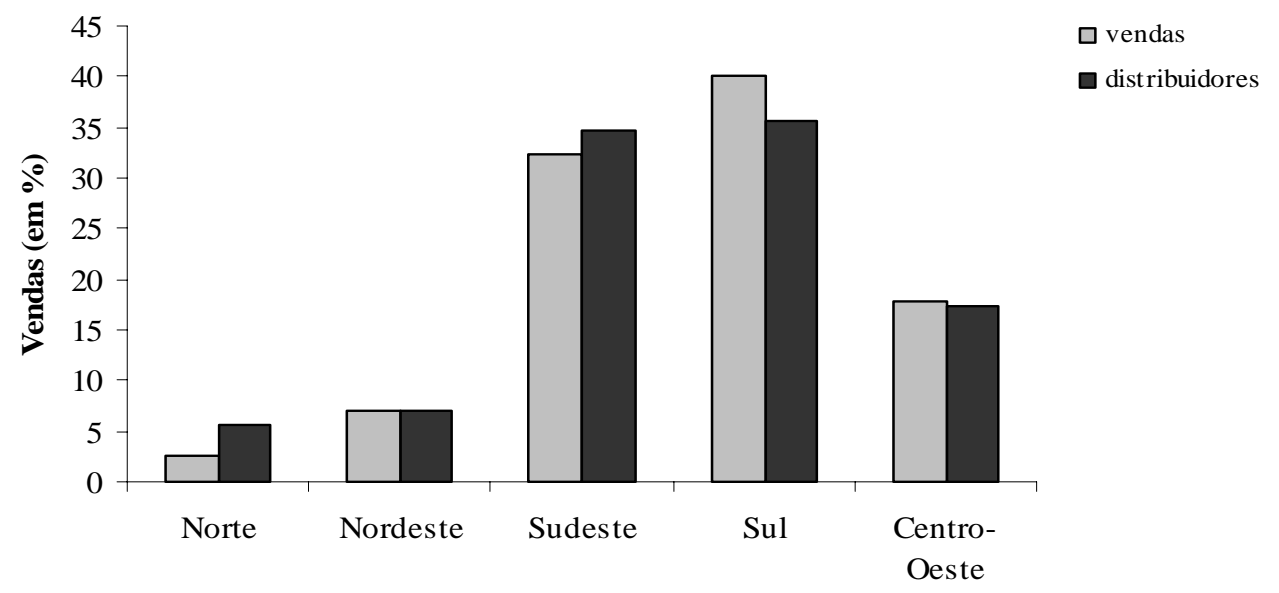

Regiões

Figura 4 - Distribuição das vendas e rede de distribuidores por região no ano de 2002 Fonte: Anfavea (2003)

A classificação dos tratores de rodas fabricados no País obedece à normalização técnica proposta pela ANFAVEA. São quarto as faixas de potência disponíveis no mercado brasileiro: 0 a 37,04 kW (0 a 49cv), 37,80 a 74,84 kW (50 a 99cv), 75,60 a 150,44 kW (100 a 199cv) e acima de 151,20 kW (200cv), Sendo mais comercializadas as de 37,80 a 74,84 kW (50 a 99cv) e de 75,60 a 150,44 kW (100 a 199 cv). De acordo com AGRIANUAL (2003), essas faixas de potência são responsáveis por mais de $75 \%$ dos tratores vendidos anualmente. A Tabela 2 mostra os resultados 
observados nas vendas ao mercado interno nos últimos três anos, demonstrando claramente a demanda por tratores de faixas de potência consideradas médias.

Tabela 2. Vendas anuais em porcentagem por faixa de potência em kW

\begin{tabular}{lccc}
\hline Faixa de potência & $\mathbf{2 0 0 1}$ & $\mathbf{2 0 0 2}$ & $\mathbf{2 0 0 3}$ \\
\hline $\mathbf{0}$ a $\mathbf{3 7 , 0 4} \mathbf{~ k W}$ & 3,85 & 3,00 & 3,05 \\
$\mathbf{3 7 , 8 0}$ a $\mathbf{7 4 , 8 4} \mathbf{~ k W}$ & 48,83 & 56,59 & 49,95 \\
$\mathbf{7 5 , 6}$ a $\mathbf{1 5 0 , 4 4} \mathbf{~ k W}$ & 46,91 & 40,16 & 46,37 \\
acima de $\mathbf{1 5 1 , 2 0} \mathbf{~ k W}$ & 0,41 & 0,25 & 0,61 \\
\hline
\end{tabular}

Fonte: Anfavea (2003)

A demanda imposta pelo consumidor por tratores de potência específicas, torna as empresas concorrentes em segmentos característicos de mercado. Esses segmentos são determinados de acordo com a faixa de potência dos tratores. Na Figura 5 é apresentada a distribuição de vendas (\%) por empresa, em conformidade com a faixa de potência.

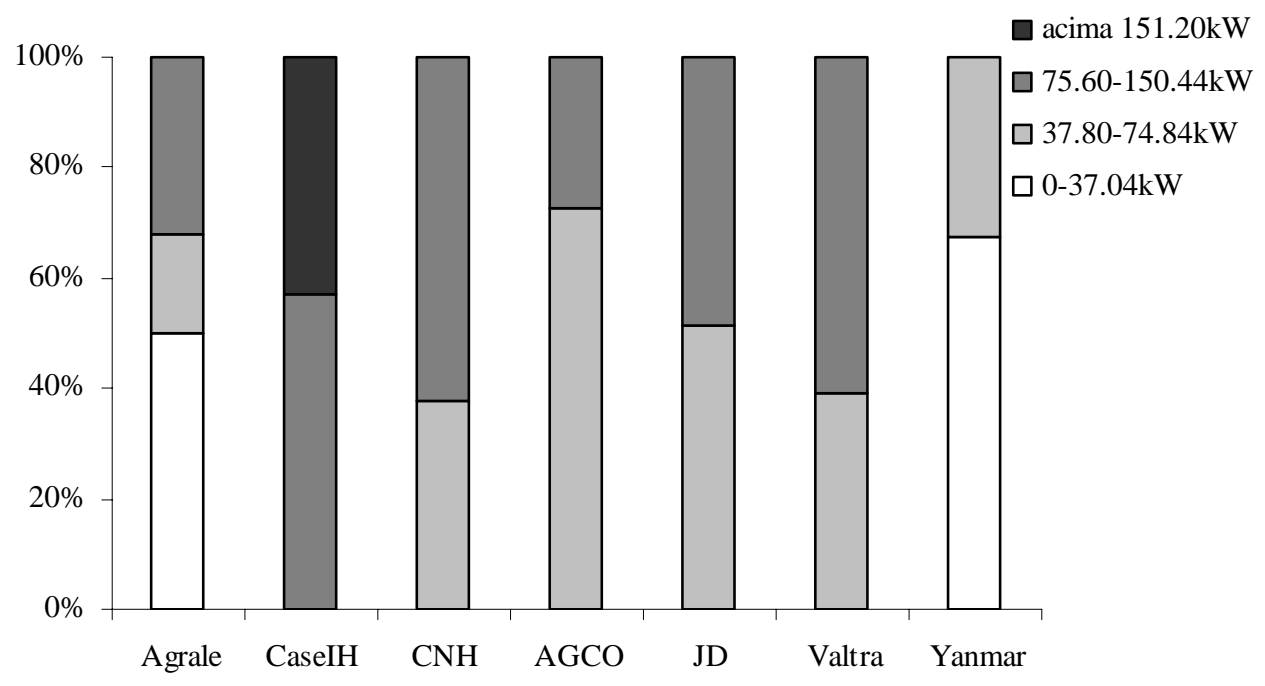

Figura 5 - Distribuição de vendas de tratores agrícolas por faixa de potência e marca no ano de 2003

Fonte: Anfavea (2003) 
O fabricante Agrale é o único que atua em três segmentos de mercado, as demais empresas optaram por produzir tratores nas faixas pelas quais iniciaram a produção no país, dessa forma mantém padronização em relação a seus produtos. As empresas AGCO ${ }^{1}$, Valtra, John Deere e CNH concorrem nos segmentos de mercado de 37,80 -74,84 kW e 75,60 a 150,44 kW, Case IH concentra-se no segmento de 75,60 $150,44 \mathrm{~kW}$ e acima de 151,20 kW, o fabricante Yanmar produz somente tratores na faixa de $0-37,04 \mathrm{~kW}$ e de 37,80 -74,84 $\mathrm{kW}$ e recentemente vendeu a linha de tratores para o fabricante nacional Agrale. Com a aquisição da Valtra, a AGCO reforçou a liderança na venda de tratores agrícolas no país. Mesmo que algumas empresas atuem em vários segmentos de mercado, buscam uma participação mais intensiva em apenas algum deles.

As três maiores empresas AGCO, Valtra e CNH que são as empresas líderes em vendas nas faixas de média (37,80 a 74,84 kW) e alta (75,60 a 150,44 kW) potência, mantêm um equilíbrio no segmento de pesados, enquanto na faixa de potência de tratores médios ocorre uma acirrada disputa, pois ele é o maior responsável por unidades vendidas. A John Deere iniciou a fabricação de tratores no ano de 1995, exatamente nesses segmentos, buscando se firmar no mercado e com essa atitude sinaliza que a disputa por vendas deve ocorrer nos tratores médios e pesados.

Nojimoto (1987) estimou as horas de uso do trator na agricultura paulista a partir de dados coletados junto às revendedoras de tratores de várias cidades do interior. No levantamento, foi verificado que, em média, os tratores trabalhavam 1107 horas/ano, valor superior ao constatado pelo Ministério da Agricultura (860 horas/ano), porém inferior ao encontrado pelo autor em uma usina de açúcar e álcool, que foi de 1357 horas/ano.

Klinger \& Mattos (1987) consideraram como amostra os tratores pertencentes a 175 produtores da Divisão Regional Agrícola (DIRA) de Marília, no estado de São Paulo, para calcular a composição do custo-hora de tratores. Os resultados mostrados indicavam uma tendência para elevação do custo-hora com o aumento da potência do

\footnotetext{
${ }^{1}$ Citação de marcas não é indicação de uso por parte do autor.
} 
trator e que combustível e mão de obra foram os fatores de maior impacto no cálculo do custo-hora.

Buscando atender ás expectativas na seleção da maquinaria de médios e grandes produtores rurais, em que a frota possui grande quantidade de modelos e equipamentos, tendo em vista a diversidade e complexidade de opções de trabalho que apresentam essas propriedades, Banchi (1989) desenvolveu um modelo matemático que usa programação linear para selecionar, quantificar e programar, tanto máquinas motoras como os implementos, determinando a melhor opção de trabalho com o mínimo custo.

A partir de dados obtidos entre 1975 e 1984, no Paquistão, Mirani et al (1989) determinaram a participação relativa dos diversos itens componentes do custo total de algumas marcas e modelos de tratores agrícolas. Os resultados encontram-se apresentados na Tabela 3.

Tabela 3. Participação relativa dos componentes do custo total para dois modelos de tratores

\begin{tabular}{lcc}
\hline Custo & Ford 4600 & MF 265 \\
& $\mathbf{( \% )}$ & $\mathbf{( \% )}$ \\
\hline Depreciação & 13,16 & 12,42 \\
Juros & 8,12 & 7,58 \\
Abrigo & 2,54 & 2,38 \\
Seguro & 0,04 & 0,03 \\
Salário do operador & 13,56 & 12,68 \\
Combustível & 38,22 & 33,69 \\
Lubrificantes & 6,84 & 2,31 \\
Reparos e Manutenção & 17,51 & 28,9 \\
\hline Fon: Mirani et al.(1989)
\end{tabular}

Fonte: Mirani et al.(1989)

Teixeira (1995) baseou-se na frota de tratores agrícolas de pneus de uma agroindústria sucro-alcooleira para determinar uma equação para estimar os custos acumulados de reparos e manutenções, tendo utilizado como parâmetro de estimativa, em função do uso do trator, medida em termos de horas anuais de operação.

Lopes (1997) desenvolveu um sistema computacional para gerenciamento de frota de tratores agrícolas de pneus (GEMA) e um sistema especialista (GEMASYS) 
para diagnosticar falhas de funcionamento do trator. O sistema de gerenciamento gera arquivos mensais a partir de dados como: o tipo de operação e de tração (leve, média, pesada), a quantidade de horas trabalhadas diariamente em cada operação, o consumo, e o preço do combustível e manutenções realizadas. O programa (GEMA) gera informações tais como custo operacional real e o valor referente a cada parcela que compõe o custo.

Oliveira (2000) determinou para a frota de tratores agrícolas de rodas de uma empresa agropecuária, composta de nove fazendas, o ponto ideal de renovação da maquinaria baseado no Custo Anualizado Equivalente (CAE). O método CAE permite evidenciar a época da troca dessas máquinas através de simulações. A substituição vai depender do uso do trator em horas, de valor inicial, das despesas anuais, de valor de revenda em cada ano e da taxa de desconto. O autor considera como decisão mais acertada a medição da vida útil em horas, podendo quantificar as horas de trabalho ao ano e o tipo de operação realizada.

\subsection{Depreciação}

A depreciação é, maior custo da maquinaria agrícola, necessário para estimar quanto o valor de uma máquina diminui com a passagem de tempo, sendo ela utilizada ou não. Deve ser avaliada para substituir os bens de capital, quando tornados inúteis pelo desgaste físico, quando perdem valor com o decorrer dos anos ou devido à incorporação de novas técnicas que venham a aumentar significativamente a capacidade produtiva do trator (obsolescência). Por representar uma parcela significativa do custo horário de máquinas e equipamentos, sua estimativa torna-se importante para a tomada de decisões relativas à substituição, à aquisição e á seleção da maquinaria agrícola (Oliveira, 2001). Sendo a depreciação um custo de propriedade deve ser alocado como custo fixo.

Existem vários métodos na bibliografia para efetuar o cálculo que estima depreciação para tratores agrícolas de rodas. Os principais métodos, de acordo com 
Hoffman et al (1976), Noronha (1981), Witney (1988), Noronha et al (1991), Teixeira (1995a), Oliveira (2000a) e Pereira (2003) são os que seguem:

a. Método da Linha Reta ou Linear

Nesse método o valor da máquina é depreciado de um valor constante ao ano pela seguinte expressão:

$$
\mathrm{D}=\frac{(P-S)}{V}
$$

onde: $\mathrm{D}=$ depreciação.

$\mathrm{P}=$ preço de aquisição do equipamento.

$\mathrm{S}=$ valor de sucata ou revenda

$\mathrm{V}=$ vida econômica, em períodos de tempo, geralmente em anos.

O método da linha reta é de utilização simplificada, não requer elaborados cálculos de matemática financeira e resulta em uma depreciação anual constante durante a vida útil da máquina. O valor de sucata é determinado nesse método, geralmente, em 10\% do preço de aquisição da máquina (Mialhe, 1974).

\section{b. Método dos Saldos Decrescentes}

Através desse método a quantidade de depreciação é diferente para cada ano de vida esperado. Em cada ano uma taxa constante de depreciação é aplicada ao valor remanescente do ano anterior.

$$
\mathrm{Dt}=B \cdot(1-d)^{\mathrm{t}-1} \cdot \mathrm{d}
$$




$$
\begin{aligned}
& \mathrm{VRt}=\mathrm{B} \cdot(1-d)^{\mathrm{t}} \\
& \mathrm{d}=1-\left(\frac{V r n}{B}\right)^{1 / \mathrm{n}}
\end{aligned}
$$

onde: $\mathrm{Dt}=$ depreciação no período $\mathrm{t}$.

B = preço de aquisição ou base depreciável.

$\mathrm{d}=$ taxa de depreciação.

$\mathrm{VR}=$ valor residual.

$\mathrm{n}$ = número que representa a idade da máquina em anos.

c. Soma dos Dígitos dos Anos

Contrariamente aos dois métodos anteriores, neste caso a taxa de depreciação decresce, mas é aplicada sempre ao mesmo valor obtido da diferença entre o valor de aquisição e o valor de descarte como sucata (P-S), como no método da linha reta. Assim, tanto a taxa de depreciação, como o valor residual, decresce à medida que o bem vai se depreciando.

$$
\text { Dn }=\left(\frac{N}{F}\right) \times(P-S)
$$

onde: Dn = taxa de depreciação no período n.

$\mathrm{N}$ = período ou ano corrente para o cálculo.

$\mathrm{F}=$ soma do digito naturais dos n períodos de vida útil.

$\mathrm{P}=$ preço de aquisição.

$\mathrm{S}=$ valor de revenda ou sucata. 


\section{d. Método do Fundo de Recuperação de Capital}

Para a utilização desse método, o cálculo da depreciação é feito de forma a compor uma reserva de capital, sobre a qual incidem juros compostos, de forma que, ao final do período correspondente à vida econômica da máquina, o recurso seja suficiente para sua reposição.

$$
\mathrm{Vn}=(P-S) \times\left[\frac{(1+i)^{L}-(1+i)^{n}}{(1+i)-1}\right]+\mathrm{S}
$$

onde: $\mathrm{Vn}=$ valor da reserva no ano $\mathrm{n}$.

$\mathrm{P}=$ custo de aquisição do equipamento.

$\mathrm{S}=$ valor de revenda ou sucata.

$\mathrm{i}=$ taxa de juros do período, normalmente anual.

$\mathrm{L}$ = ano corrente para o cálculo, ano n.

e. Valor de Mercado

Para o calculo da depreciação, esse método utiliza uma pesquisa de mercado, de modo a estabelecer o real valor da maquinaria usada, coletando os preços das máquinas em concessionárias.

Existe um método muito comum nos EUA para cálculo da depreciação e do valor residual para tratores ASAE (1996). O método utiliza uma função geométrica, na qual a porcentagem de valor residual é calculada em função da idade da máquina.

Segundo Noronha (1981), depreciação é uma reserva contábil destinada a promover os fundos necessários para a substituição do capital investido em bens produtivos de longa duração, em função do desgaste e /ou da obsolescência. Conforme Duarte et al (1988), a depreciação é o custo pelo uso ou obsoletismo, quando a vida útil de uma máquina ultrapassa um ano de uso. De acordo com os autores, esse item recebe 
especial atenção da maioria dos trabalhos que tratam dos custos de sistema mecanizados agrícolas, pois representam a maior parte do seu custo total.

O conceito financeiro de depreciação, conforme Padoveze (1991), é o valor ou custo da recuperação dos valores gastos na realização dos investimentos no negócio. Esse custo deve ser considerado na análise de retorno do investimento.

Para Hirschfeld (1992), a depreciação é a diminuição do valor de um bem, sendo ela de natureza real ou contábil. A depreciação real é a diminuição efetiva do bem, resultante do desgaste pelo uso, pela ação da natureza ou pela obsolescência normal. A depreciação contábil é a diminuição, em valores contábeis, resultante do decurso de prazo entre a data de aquisição e o instante em que se calculam os custos atribuídos ao desgaste físico ou obsolescência. O desgaste é típico dos equipamentos cuja eficiência decresce gradativamente com o tempo, ou com o uso, provocando aumento nos custos, além de prejudicar a qualidade no serviço prestado e diminuir a eficiência produtiva.

O conceito de depreciação econômica, segundo Perry (1997), é a perda de valor real da máquina agrícola no mercado local, isto é, a diferença entre o valor de aquisição e o valor da máquina em qualquer transação futura. Depreciação econômica é um custo que incide sobre a maquinaria nova ou usada.

Segundo Kasten (1997), depreciação é a diminuição de um recurso, com o passar do tempo, por causa da idade, uso, obsolescência e mudanças nas condições de mercado. O autor afirma que a precisa estimativa de depreciação é necessária na administração da propriedade agrícola.

Edwards et al (2001) considera a depreciação como um custo de propriedade que aumenta em proporção direta com o tamanho e o investimento na maquinaria. Segundo Jorgenson (1996), a depreciação de um bem durável é representada pela queda no seu preço, refletindo a redução corrente e o valor presente nas reduções futuras da eficiência do equipamento. Para Fraumeni (1997), depreciação é o declínio em valor, devido a desgaste, obsolescência dano acidental e envelhecimento. Conforme Griliches (1963), a queda no preço do bem reflete, na realidade, o comportamento de três componentes de difícil separação: deterioração, obsolescência e exaustão. A deterioração reflete a menor produtividade da vida útil restante; a obsolescência indica a 
redução no preço do bem, decorrente do surgimento de modelos mais avançados tecnologicamente; e a exaustão refere-se à redução na vida futura do bem.

De acordo com Mialhe (1974), vida útil é o tempo que decorre entre a compra do equipamento e a sua rejeição como sucata, mas que, no entanto, deveria ser visto como seu tempo de uso econômico. Hunt (1973) classifica a vida útil da maquinaria como física, econômica e contábil.

Barger et al. (1966) consideram que a vida útil da maquinaria agrícola não diz respeito somente ao tempo de uso, mas à sua intensidade de uso, a conservação, obsolescência e a mudança de atividade da empresa agrícola. Comentam também a dificuldade na estimativa da depreciação dos equipamentos, decorrente da inexatidão na avaliação da vida útil.

Notonha et al.(1991) consideram que a vida útil está sendo definida de modo vago. Muitos autores consideram 10 anos como a vida útil do trator, independentemente de seu uso e da intensidade deste. Outros consideram-na como sendo de 10 mil horas, sem levar em conta o surgimento de modelos mais avançados tecnicamente. O Instituto de Economia Agrícola (IEA), baseado em suas pesquisas estima o tempo de duração de máquinas e equipamentos, sugerindo parâmetros que podem ser úteis na determinação da depreciação (Tabela 4).

Tabela 4. Estimativa de Duração de Máquinas e Equipamentos

Máquina e equipamento

Trator de rodas

Trator de esteiras

Caminhão

Carreta de trator

Fonte: IEA (2003)

\section{Duração em anos}

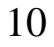

10

7

10

Alguns autores explicam que, se a vida útil da maquinaria for definida de forma quantitativa, ou seja, sendo calculada a duração com a duração da máquina em funcionamento, será comum encontrarmos dados de campo que revelem longos períodos 
de vida útil. Fraumeni (1997) estima a vida útil do trator agrícola em 9 anos, sem mencionar a intensidade do uso. Levando em conta a qualidade do trabalho realizado pelo trator é possível obter uma melhor avaliação de sua vida útil. Cross (1995) define vida útil como o total de horas esperadas de uso, dividido por horas anuais de uso, assim, quanto menor for a vida útil maior será a taxa de depreciação. Dessa forma, quando surge um trator substituto com capacidade de efetuar as mesmas operações de maneira economicamente mais eficiente encerra-se a vida útil do trator em uso (Oliveira, 2000a).

Ressaltando a necessidade permanente de administrar os ativos imobilizados, Leite (1993) afirma que, para assegurar um contínuo desenvolvimento empresarial, considerando que há avanço tecnológico, a substituição da máquina sucateada deverá ser por máquina nova mais eficiente. O autor considera que, no período de uso, a tecnologia progrediu, novos sistemas de produção foram desenvolvidos e, conseqüentemente, a máquina nova que entra em operação não deve ser a mesma que foi retirada.

Klinger \& Mattos (1987), em pesquisa realizada na Divisão Regional Agrícola (DIRA) de Marilia, encontraram tratores das mais diversas idades, que foram classificados em 5 grupos, de acordo com a faixa de potência: 30,24 a 34,02 kW - a idade média observada foi de 23 anos; 45,36 a 47,62 kW - a idade média foi de 25 anos; 52,92 a 55,18 kW - a idade média foi de 13 anos; entre 56,70 a 67,28 kW - idade de 15 anos; e para 81,64 kW idade média de 7 anos. Constataram os autores que os resultados se devem ao fato dos agricultores estarem retardando a renovação da frota de tratores, possivelmente pelo alto custo do crédito para investimento, o que explicaria a existência de tratores com até 25 anos de idade nos dados coletados.

Observando a frota brasileira de tratores agrícolas, BUSSAD (1997) considera que a média de idade de um trator naquele ano era por volta de 8 a 9 anos e avalia como economicamente viável um trator trabalhar, pelo menos, 800 horas/ano, devendo a sua vida útil ser em volta de 10.000 horas trabalhadas. Concluiu, ainda, que as máquinas deveriam ser utilizadas por, no máximo 12,5 anos, após o que seria mais barato trocá-las por um novo equipamento do que continuar as reformas.

O tempo de uso econômico, segundo a teoria dos custos de Hoffmann et al (1976), é definido através dos custos operacionais da máquina ao longo da vida útil. Para 
Noronha et al (1991) é importante estar atento a fatores que possam diminuir a vida útil do trator.

Máquinas, veículos e equipamentos são bens de capital, adquiridos pelo empresário agrícola na expectativa de gerar um fluxo de serviços, ao longo do tempo, para as atividades agropecuárias desenvolvidas na sua empresa (Martin et al 1998). A estimativa dos custos derivados desses bens de capital é complexa, uma vez que os custos vão depender do preço, do uso anual e da vida útil. De acordo com o autor, a alternativa mais viável seria avaliar o bem de capital pelo custo de reposição por um novo bem, igual ou semelhante ao que se deseja estimar o custo.

Comparando os métodos de cálculo de custo de produção utilizados por 33 instituições, Turra (1990) verificou que todos usavam o método de depreciação linear. Uma das justificativas para a utilização desse método é a simplicidade em se fazer o cálculo, entretanto, ele não reflete a perda de valor, que normalmente é maior nos primeiros anos de uso. A outra justificativa para adoção do método tem base na legislação do imposto de renda, que adota o método da linha reta como padrão legal para depreciação.

Mayfeld et al (1981), realizaram um levantamento, entre 1977 e 1980, para determinação dos custos totais de tratores agrícolas. Para o cálculo da depreciação não foram empregados os métodos normalmente estabelecidos e sim uma pesquisa de mercado para obtenção do valor de revenda dos tratores, sobre o qual foi considerada a taxa média de juros do respectivo período.

Balastreire (1990) afirma que a melhor estimativa para depreciação seria o valor corrente de mercado da máquina em consideração. O autor lembra que o mercado brasileiro ainda não era suficientemente organizado para fornecer dados periódicos confiáveis sobre os preços praticados na revenda de máquinas agrícolas usadas.

Molina \& Canale (1998) analisaram os preços de tratores agrícolas de rodas, fornecidos semanalmente pelo suplemento agrícola (Agrofolha) do jornal Folha de São Paulo, no período de 1989 a 1991. O preço de tratores novos constava na relação publicada como valor sugerido pelo fabricante, determinado como preço de lista. Para o valor de usados, os dados eram os fornecidos pelo DATAFOLHA, em coleta realizada 
junto aos revendedores especializados de todo o Brasil. Os autores observaram que no primeiro ano o trator sofre uma perda de aproximadamente $30 \%$ do custo de aquisição; a depreciação tende a ser linear a partir do segundo, com taxas próximas a 10 \% e o valor de revenda situa-se em torno de 30 \% do preço de aquisição. Nesse levantamento a idade média dos tratores era de 15 anos.

Calculando o estoque de tratores agrícolas no Brasil, Barros (1999) estimou a taxa média de depreciação para dois modelos, determinando uma equação pelo método de Mínimos Quadrados Ordinários. A taxa de depreciação chegou próxima a 6,1\% ao ano. Foi utilizada, para o cálculo do valor de estoque, a taxa de $6 \%$ ao ano e a vida útil adotada para o trator foi de 21 anos, com base nas vendas de tratores agrícolas no Brasil.

Rezende \& Valverde (1997) analisaram e comparam os principais métodos de depreciação e os confrontaram com o método linear. Utilizaram no estudo um trator florestal arrastador (Skidder) e um veículo transportador (caminhão). Concluíram que, dos vários métodos estudados, o método de Cole foi o que mais se aproximou do valor real de mercado.

Perry et al (1990) analisaram os preços de tratores usados apresentados no Farm Equipament Guide, publicação especializada em preço de leilão para equipamentos de fazenda em diferentes partes do EUA. Verificaram que a depreciação real dos tratores é muito próxima ao resultado do método da soma dos dígitos dos anos. O estudo também revelou que os tratores com uso intensivo não sofreram grandes reduções de preço, mas tratores com baixo uso anual alcançaram preços melhores nos leilões.

Em coleta de dados sobre o preço de tratores agrícolas na faixa de potência de 68,04 a 124,74 kW, no período de 1984-1988 em todo território americano, publicada pela Hot Line, Perry (1990) determinou quatro modelos. Os modelos usavam variáveis de parâmetros como: com e sem valor de sucata, uso e condição geral. Como esperado, a idade foi a única variável expressiva nos quatro modelos, porém seu impacto diminuía com a inclusão de uso. O autor ressalta que o uso da maquinaria e o cuidado com seu estado de conservação podem afetar a taxa de depreciação do trator agrícola. 
Hansen et al (1990) determinaram um modelo empírico em uma amostra de 1612 tratores americanos na faixa de potência de 45,36 kW e os dados obtidos variaram de potência entre 43,84 e 47,62 kW. Esta faixa de potência, segundo os autores, exemplificaria uma série de preços confiáveis de tratores agrícolas, uma vez que os principais fabricantes mantêm a produção de tratores desse porte com variações somente em termos de modelo. $\mathrm{O}$ trabalho utilizou preços de tratores com dez anos de idade, ou menos, coletados no período 1960-1988 pelo Official Guide Tractors and Farm Equipament e publicado pela Associação Norte Americana de Negociantes de Equipamentos Agrícolas. Os dados fornecidos, além do preço, foram ano de fabricação, modelo e fabricante. Para efeito de análise, a maquinaria foi dividida em três períodos: tratores fabricados de 1960 até 1969, 1970 a 1979 e os produzidos no período de 1980 até 1988. Os autores concluíram que a taxa de depreciação para essa situação está próxima à taxa de $8,3 \%$, sendo consideravelmente abaixo da maioria das estimativas prévias.

Perry et al (1990) pesquisaram os preços de 1.030 tratores usados, com faixas de potência que variavam de 60,48 a 113,40 kW, vendidos em leilões nos EUA no período 1985-1988. Os dados fornecidos pelos leilões eram sobre tratores fabricados a partir de 1971, incluindo marca, idade, horas de uso, potência e estado de conservação. Os dados relacionados à conservação do trator foram avaliados de forma subjetiva pelos leiloeiros, numa escala de 1 (excelente) a 4 (pobre). Os autores concluíram que os tratores com maior potência são destinados a operações agrícolas mais intensas e por isso, depreciariam mais rapidamente que os de menor potência, resultando em taxas de deterioração mais rápidas.

Cross \& Perry (1995) afirmaram ser necessários novos modelos para predizer o valor de mercado e o gasto com depreciação da maquinaria e equipamento agrícola. Os quatro modelos usados pela ASAE para determinar o valor de mercado da maquinaria permanecem inalterados desde a sua determinação em 1971. Os autores atualizaram e ampliaram para nove o número de modelos para calcular o valor residual / mercado de tratores e equipamentos agrícolas. Os dados analisados para determinação dos modelos foram coletados do Farm Equipament Guide de janeiro de 1984 a junho de 1993. A fim 
de reduzir a análise foram observados somente os preços de colhedoras e tratores que possuíam números totais de horas de uso e os dados coletados se restringiram às máquinas e equipamentos fabricados entre os anos de 1971-1993. Além do preço de venda, cada leilão forneceu o ano de fabricação, horas totais de uso, modelo e fabricante, local da venda, tipo de leilão, condição do equipamento e opcionais (por exemplo, cabine, ar condicionado). Para os autores, apesar de normalmente ser utilizado um único modelo para várias faixas de potência dos tratores agrícolas, modelos mais precisos e úteis podem ser conseguidos subdividindo os tratores em três categorias: 22,68 a 59,72 $\mathrm{kW}, 60,48$ a 113,40 kW e acima de 113,40 kW.

Cross et al (1996) propuseram modelos a fim de tornar mais consistente o cálculo de valor residual para tratores e implementos agrícolas. O padrão ASAE previa uma função para calcular o valor residual de tratores e quatro para equipamentos agrícolas, mas os autores argumentaram que o aumento de 04 para 12 modelos melhora sensivelmente a representação dos padrões de depreciação para implementos e sugeriram uma função reduzida para tratores. Foram obtidos preços de venda em leilões de maquinaria agrícola e equipamentos em todo os EUA, publicados mensalmente no Farm Equipament Guide. Somente foram considerados os dados de tratores fabricados entre 1971-1993 e nos leilões ocorridos no período de janeiro de 1984 a junho de 1993. Juntamente com as informações sobre os tratores foram coletados dados referentes à condição, ou seja, estado de conservação da maquinaria vendida, os quais foram classificados com notas que variavam de 1 (pobre) até 4 (excelente) sendo as notas atribuídas a critério de cada leiloeiro. Conforme os autores, os modelos sugeridos responderam melhor à necessidade de estimar os valores de mercado, tanto de tratores como de outros equipamentos agrícolas, sendo recomendados para substituir o padrão da ASAE.

Dumler (1998) comparou seis diferentes métodos de depreciação, usados para predizer o valor de mercado de tratores agrícolas norte americanos. O trabalho obteve os dados de preço de vendas, retirando-os do Farm Equipament Guide. Foram selecionados tratores com potência acima de 75,60 kW, produzidos entre 1975-1995, a fim de determinar o método que mais se aproximava do valor residual ou do valor de mercado, 
tendo sido constatado que os métodos utilizam diferentes fatores para determinar o valor residual e possuem distintos graus de dificuldades para aplicação. Os fatores são: idade, intensidade de uso, condição do vendedor e fabricante.

A correta determinação da desvalorização do bem não é um procedimento simples, pois ela é avaliada como um sério problema na administração da maquinaria agrícola com mais de um ano de uso. Um trator pode contribuir durante vários anos para a geração da receita, devendo, portanto, seu custo inicial ser distribuído entre as despesas dos vários períodos nos quais ele prestou serviços, de modo que seu valor inicial diminua gradativamente até o momento em que não tenha mais capacidade de fornecer serviços produtivos. A depreciação será mais ou menos elevada, dependendo da intensidade de utilização do trator, afetando o preço de revenda obtido no mercado.

\subsection{Métodos de pesquisa}

Segundo Richardson et al (1995) é fundamental selecionar o método adequado para pesquisa de dados, para atingir os objetivos desejados com os recursos disponíveis para essa tarefa. A Figura 6 ilustra esta inter-relação.

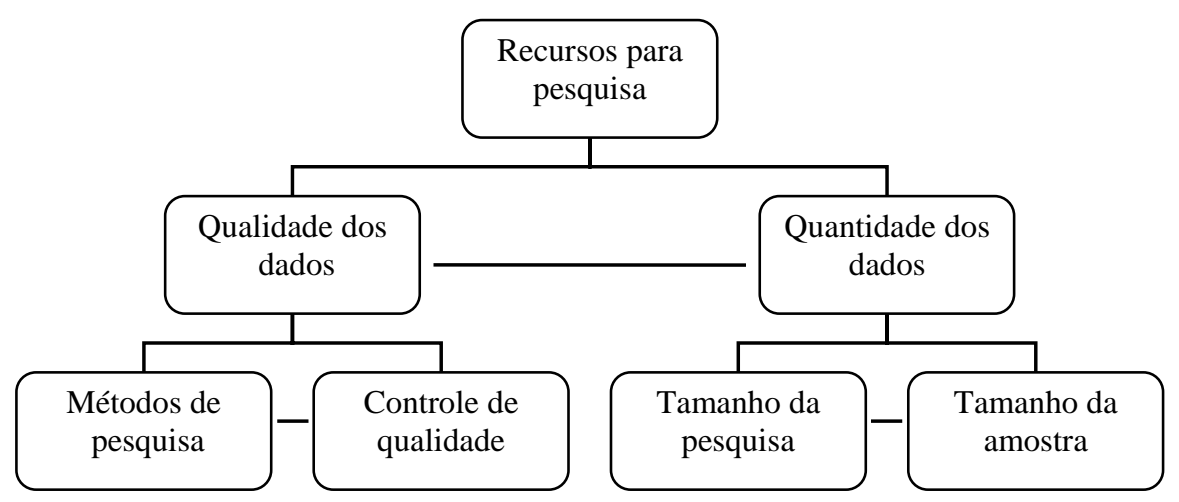

Figura 6 - Inter-relação entre fatores que definem uma pesquisa, adaptado de Richardson et al (1995)

Conforme o mesmo autor, existem 8 tipos de técnicas de coleta de dados: 
a) busca documental: quando o objetivo é uma simples busca de documentos publicados e não publicados e banco de dados para descobrir a informação desejada;

b) pesquisa de observação: focada na obtenção de dados por verificação in loco e normalmente usada para validar resultados obtidos de entrevistas individuais e/ou de pesquisa de auto preenchimento;

c) pesquisa de abordagem: é conduzida fora do domicílio, enquanto o entrevistado usa um modo qualquer de transporte. Não há regra definida quanto à seleção dos entrevistados e ocasiona o desconhecimento da população da qual amostra é retirada;

d) pesquisa domiciliar de entrevista: é caracterizada pelo entrevistador, que faz as perguntas e anota as respostas (pesquisa de abordagem e tele marketing estão incluídas aqui);

e) pesquisa grupal: ideal para testes pilotos de questionários, quando ainda não se tem uma perspectiva segura do que será descoberto;

f) pesquisa em profundidade: orientada para penetrar abaixo da superficialidade das pesquisas de formato perguntas e respostas, caracteriza-se por entrevistas longas, que são gravadas, podendo ser em individuais ou em grupo;

g) pesquisa telefônica: com abordagem de baixo custo e com raio de abrangência geográfico maior, possui as desvantagens de ser longa e da baixa tolerância por parte do entrevistado;

h) pesquisa de auto preenchimento: forma de pesquisa muito utilizada em sistemas de transporte, caracterizada por três fases: leitura e entendimento da questão, racionalização da resposta e transcrição para o questionário. Costuma ser mais barata que a pesquisa de entrevista individual e propicia ao entrevistado maior tempo para responder as questões, o que facilita uma consulta mais detalhada, embora apresente a desvantagem do baixo índice de respostas.

Rea \& Parker (1997) apontam que o questionário é uma forma organizada de se obter e registrar informações específicas e relevantes com a exatidão e a abrangência 
necessárias. Os autores afirmaram que a comunicação via questionário não é limitada às entrevistas por telefone, pelo correio ou Internet.

Conforme Lakatos \& Marconi (1999), a construção de um questionário é composta de seis etapas. São elas: decisão sobre que informação deve ser procurada; definição sobre que tipo de questionário deve ser usado; redação de uma primeira versão; revisão de questões; pré-teste e revisão do questionário; especificação dos processos de seu uso.

De acordo com Mattar (1993), na definição do questionário são importantes a sensibilidade, a experiência e o conhecimento das opções de como perguntar.O autor diz que a construção do questionário é um processo cíclico e interativo, uma vez que o pesquisador deve testá-lo até que ele esteja pronto para aplicação.

Ainda conforme o mesmo autor, a pesquisa descritiva é usada quando houver o propósito de descrever as características do grupo; estimar a proporção de elementos numa população específica, que tenham determinadas características ou comportamentos; descobrir ou verificar a existência de relação entre as variáveis. 


\section{MATERIAL E MÉTODOS}

O trabalho consta basicamente de uma pesquisa para o levantamento, no mercado, de preços de venda de tratores agrícolas de rodas usados e da comparação dos valores obtidos (valor real de mercado) com os modelos de depreciação encontrados na bibliografia.

\subsection{Levantamento de preços de tratores usados}

Para o levantamento dos preços dos tratores agrícolas usados foi necessário desenvolver um questionário, definir um público alvo e a forma de obtenção das informações. Em um primeiro momento foi elaborado um questionário preliminar para teste da metodologia e, depois de efetuadas as devidas correções com base no teste preliminar, iniciou-se a fase principal do levantamento.

\subsubsection{Desenvolvimento do questionário preliminar}

O instrumento da coleta de dados (o questionário) utilizou a metodologia proposta por Marconi \& Lakatos (1999). o questionário foi construído a fim de determinar o estado de conservação dos tratores, com perguntas de múltipla escolha, visando os responsáveis pelo preenchimento das informações e considerando que há nos revendedores, um setor de vendas de máquinas novas e usadas e alguém responsável pela avaliação desse tipo de maquinaria. Nesse questionário, um ponto importante a ser 
considerado, além da identificação precisa do espécime, é o estado de conservação do equipamento, que pode influenciar no valor de venda do equipamento.

A metodologia básica e a elaboração obedeceram ao método de avaliação sugerido por Mialhe (1980) e Saad (1956), onde o trator seria avaliado segundo o estado de conservação dos seus principais componentes.

\subsubsection{Identificação do trator avaliado}

Alem das informações que identificassem o trator avaliado e seu estado de conservação, conforme proposto por Mialhe (1974), foram solicitadas outras informações de fácil obtenção, pois geralmente estão disponíveis em plaquetas na própria estrutura da máquina: a marca, o modelo, o ano de fabricação, o motor, a potência, o tipo de tração, o número de horas trabalhadas ou estimadas, o preço de venda e o tipo de proprietário.

\subsubsection{Componentes analisados}

Sistemas que compõem um trator agrícola, a subdivisão em seis grupos, teve como objetivo analisá-los inicialmente de forma individual e posteriormente de forma global. Os grupos de componentes são: visual, motor, transmissão, hidráulico, pneus, componentes elétricos.

\section{a- Grupo visual}

O primeiro grupo de indicadores, denominado no questionário como visual, está composto pelos aspectos aparentes do trator, itens que são observados inicialmente pelo avaliador. Este grupo é composto pelo painel de instrumentos, assento do operador, alavancas de comando, lataria, pintura, barra de tração e volante (direção). Pela facilidade de acesso e baixos custos esses elementos têm uma melhor manutenção. 


\section{b- Grupo hidráulico}

O segundo grupo de elementos, nomeado grupo hidráulico, mostra o perfil dos componentes externos do trator relacionados ao grupo, mas com foco nos elementos do sistema, responsáveis por transformar e transmitir potência do motor aos cilindros hidráulicos. Os itens analisados são três: direção, engate de três pontos (levante hidráulico) e vazamentos do sistema.

\section{c- Grupo motor}

São dez os elementos avaliados, subdivididos em: correias (do motor, radiador, direção hidráulica e ar condicionado, havendo a existência deste item); tanque de combustível; sistema de injeção e filtros de combustível; purificador de ar e mangueiras que compõem o sistema de purificação; radiador e as mangueiras que compõem o circuito de arrefecimento de água do trator; carter; vazamentos de óleo (lubrificantes, combustível ou hidráulico); coletor de escapamento, admissão e silencioso; bomba de água; ruídos do motor.

\section{d- Grupo componentes elétricos}

O quarto grupo é composto por bateria, fonte de energia para o sistema elétrico (usada para acionamento do motor); cabos e terminais (sendo os primeiros usados para a transferência da energia dentro sistema elétrico os terminais para fixar os cabos ao circuito elétrico), faróis e lanternas, alternador (componente destinado a fornecer energia para o circuito elétrico com o motor em funcionamento) e motor de partida (sistema que, ao ser acionado, promove ao acionamento do motor).

\section{e- Grupo transmissão}

No quinto grupo encontram-se os mecanismos que possibilitam a variação de velocidade frente às exigências da barra de tração e do rodado em relação ao tipo de solo. Foram avaliados itens de embreagem, mecanismo destinado à conexão do motor aos demais órgãos de transmissão; caixa de câmbio, diferencial; tomada de potência; e freios. 


\section{f- Grupo pneus}

O sexto grupo foi composto de elementos da parte rodante. Os componentes deste grupo que é baseado no rodado do trator, são: pneus dianteiros, pneus traseiros, eixo e rodas.

\section{g- Grupo opcionais}

Por se tratar de tratores usados, com diferentes números de anos, marcas, faixas de potência, tipo de proprietários e aplicações, poderia haver espécimes com itens considerados como opcionais, ou seja, não comumente encontrados em determinada categoria de trator, direção hidráulica, cabine, ar condicionado, entre outros. Nesse campo seria anotado, pelo avaliador, o tipo de opcionais encontrados.

\subsubsection{Indicador do estado geral}

Para avaliar o estado de conservação da maquinaria foi estabelecida uma escala onde constavam os indicadores de conservação de 1 a 5, atribuídos ao estado em que se encontrava cada componente avaliado do trator: ruim (1), regular (2), bom (3), muito bom (4) e ótimo (5). As notas deveriam ser atribuídas a cada um dos itens avaliados.

A proposição de uma escala de indicadores baseou-se na necessidade de avaliar diferentes itens da composição do maquinário agrícola, em seus distintos estados de conservação. A escala de Lickert, de acordo com Marconi \& Lakatos (1999), é uma escala empregada nos questionários de pesquisa de marketing e sociologia e revelou-se a mais indicada, devido à sua aplicabilidade e potencialidade em determinar notas aos espécimes avaliados. A escala era composta de uma classificação, de 1 a 5 , sendo os valores correspondentes à desaprovação, desaprovação incompleta, neutralidade, aprovação e aprovação completa. Para esta pesquisa, a nota 1 é indicativa de que o estado de conservação é ruim, 2 demonstra um estado regular, 3 diz ser bom o estado de conservação, 4, muito bom e 5, ótimo estado. 
Além da análise individual de cada item do trator, foi incluído um campo para a condição geral do trator analisado, onde o avaliador colocaria, em uma única nota, a sua avaliação da máquina, seguindo a escala de mensuração descrita para os indicadores de estado de conservação.

\subsubsection{Teste preliminar}

Determinadas as informações necessárias e definida a população, foi realizado um teste piloto, com a finalidade de verificar a consistência e confiabilidade do questionário. Esse teste foi aplicado numa amostra de 26 tratores, escolhidos aleatoriamente junto a revendedores autorizados e autônomos na cidade de PiracicabaSP em janeiro de 2003.

\subsubsection{Questionário definitivo}

As informações empregadas para elaboração deste estudo foram obtidas através de pesquisa de auto-preenchimento, utilizando-se um questionário confeccionado, inicialmente, para permanecer em uma pagina da web, denominada “tratores” na home page da Escola Superior de Agricultura “Luiz de Queiroz”.( www.esalq.usp.br/tratores). A opção pelo questionário virtual deveu-se à distância e ao número de concessionárias de tratores agrícolas existente no Brasil.

As informações referentes à rede de distribuidores de máquinas agrícolas, levantadas junto ao site da Associação Nacional dos Fabricantes de Veículos Automotores (Anfavea), revelaram que a região nordeste possui 43 concessionários, a região norte 72, a sudeste 270, a sul 277 e a centro-oeste 136. Portanto, o número total de revendedores de tratores agrícolas no Brasil situa-se em 413. 


\subsubsection{Método da pesquisa}

O questionário não foi enviado, como ocorre normalmente, optando-se por colocá-lo fixo na home page da ESALQ-USP e solicitar aos revendedores que acessassem a página e inserissem as informações, formando assim um banco de dados. Essa medida foi tomada na intenção de assegurar credibilidade à pesquisa. Foi, ainda remetido por correio eletrônico aos gerentes de vendas ou diretores das concessionárias um arquivo em formato $\operatorname{Word} \circledast$, solicitando a participação do revendedor, explicando o objetivo do trabalho e determinando um prazo de 30 dias (iniciava no dia 15 de julho de 2003 a 15 de agosto de 2003) para acesso.

Para determinar o numero de concessionárias foi feito um primeiro levantamento junto ao site da Associação Nacional dos Fabricantes de Veículos Automotores (Anfavea). Posteriormente, em consulta a sites dos fabricantes de tratores agrícolas foi feito o levantamento e cadastramento do endereço eletrônico de cada uma das concessionárias e do responsável pela área de vendas de tratores usados, quando houvesse ou gerente geral, a fim de enviar o arquivo contendo a solicitação para a participação na pesquisa.

\subsubsection{Página Internet}

Para facilitar o cadastramento e permitir a participação de concessionárias de todo o país optou-se por utilizar a rede Internet como plataforma. Foi escolhido o servidor de Web da Escola Superior de Agricultura “Luiz de Queiroz”- ESALQ-USP por ser estável e garantir para a pesquisa credibilidade, condição imprescindível na inserção, aquisição e manutenção de dados.

Para implementar o cadastro foram criadas duas tabelas, uma determinando o trator e a outra a marca no banco de dados da ESALQ. A estrutura da tabela de trator descrimina o trator a ser avaliado e os itens que compõem essa avaliação, a outra apresenta as marcas dos principais fabricantes nacionais de tratores agrícolas de roda e 
pode ser vista em anexo deste trabalho. O banco de dados utilizado foi o MySQL, rodando em plataforma Linux ${ }^{\circledR}$.

Foi implementada uma página de web no servidor da ESALQ (www.esalq.usp.br/tratores/) onde, além do formulário, foram colocadas todas as informações que pudessem ser de interesse dos participantes. Foi utilizada a linguagem script PHP para efetuar as rotinas de adição dos formulários e para resguardar os dados da pesquisa, foi registrado o endereço IP das máquinas pelas quais os usuários fizeram o cadastro. Este endereço é importante para conhecimento da procedência do registro em caso de alguma anormalidade ou de ataques virtuais.

Os dados inseridos no banco de dados, depois de conferidos, a fim de monitorar possíveis erros no preenchimento, foram padronizados, porque houve casos em que um mesmo modelo foi descrito de diversas maneiras, provavelmente em virtude de preferências regionais. Após encerrar a coleta, os dados foram exportados para planilha eletrônica (excel $\circledast$ ) para posterior análise.

\subsection{Obtenção do valor inicial}

Os valores dos tratores usados foram convertidos em valores relativos ao do trator novo do mesmo modelo ou, quando o modelo não era mais fabricado, ao do modelo correspondente do mesmo fabricante, considerando a mesma faixa de potência e dividindo-se o valor coletado da máquina usada pelo preço de lista do trator novo. A metodologia descrita é proposta por Barger (1966), Cross (1995) e Molina (1998).

\subsubsection{O valor do trator no jornal “O Estado de São Paulo”}


Há necessidade de definir o preço de venda de tratores novos para esta pesquisa, ou seja, estabelecer um referencial, a fim de conhecer o preço base de comercialização. Para esse fim, foram utilizados os dados constantes no suplemento agrícola do periódico “O Estado de São Paulo”, de 06 de agosto de 2003, onde são publicadas duas espécies de tabelas: uma com o preço de venda de tratores agrícolas novos, determinado para este trabalho como preço lista, e outra com o preço de tratores usados, coletados em revendedores estabelecidos no interior do estado de São Paulo.

\subsubsection{Valores dos tratores usados}

A metodologia de avaliação está baseada em Mialhe (1974 e 1996). Para determinar o estado de conservação, a estrutura do trator foi subdividida em seis grupos de componentes: visual, motor, hidráulico, componentes elétricos, transmissão e pneus.

No campo definido como visual, estão componentes visíveis e a presença de danos é facilmente notada, considerado a aparência e o funcionamento dos itens em relação a um trator novo. O painel de instrumentos foi avaliado pelo aspecto, pelo funcionamento de luzes e indicadores, pela visibilidade da escala dos mostradores; no assento verifica-se a situação do encosto e da regulagem; na lataria foi observada a fixação em relação à estrutura do trator, a ocorrência de ferrugem e dobras e a falta de partes como pára-lamas, capô ou laterais; a pintura foi avaliada no aspecto de conservação, verificando-se a cor do fabricante, identificação de marca e modelo.

A barra de tração foi analisada em relação à dificuldade no acoplamento de máquinas ou equipamentos e quanto aos dispositivos de fixação do implemento na barra. No volante foi verificada a presença de danos e a falta de emblema do fabricante ou material que compõe a circunferência da direção.

No grupo motor foram analisados alguns itens: correias, foram verificados pela análise do estado, basicamente pela aparência; o tanque de combustível, por vazamentos, tanto no corpo do tanque como no bocal de abastecimento; o sistema de injeção de 
combustível e filtros de combustível e lubrificante, por vazamentos e pelo estado dos elementos filtrantes; as mangueiras, canos; purificador de ar e mangueiras tiveram observada a condição do purificador; a integridade das mangueiras, presença de cortes ou rachaduras; o radiador e mangueiras do sistema de arrefecimento; foi verificada, pela condição aparente das mangueiras, a presença de danos que possam comprometer a circulação ou perda de água pelo sistema; no carter, foi verificada a presença de soldas e de vazamentos de óleo; a bomba d’água foi avaliada pela presença de ruídos, vazamentos ou fissura na carcaça; no funcionamento do motor do foram avaliados os ruídos trator com uma pequena carga e, posteriormente, à meia carga,.para, dessa forma escutar e constatar alteração nos ruídos e surgimento de barulhos.

Os itens vistoriados no campo hidráulico foram: a direção hidráulica, na qual é avaliado o funcionamento da direção, em trabalho ou manobra, constatando dificuldades na alteração de sentido, ruídos ou folga na direção; o engate de três pontos, no qual é verificada a condição dos braços e da barra de acoplamentos, e se são íntegros ou soldados, se os pontos de acoplamento e engate possuem folga em relação ao braço e desgaste excessivo provocando, desta forma, folga ao se acoplar ao equipamento ou máquina, se as regulagens das conexões de levante estão operando, se não ocorre folga na árvore de acionamento dos braços de levante; existência de vazamento, para o qual foi verificada a presença de óleo de hidráulico no cilindro; acionamento do engate de três pontos, indo do início até o final do curso compreendido do sistema, a fim de simular o levante máximo e mínimo do curso do pistão hidráulico.

Para os componentes elétricos foram verificados os itens relacionados com o funcionamento do motor: bateria, motor de partida, alternador e faróis e lâmpadas cabos. Na avaliação da bateria, foi observada a deformação nos pólos, ranhuras e fissuras na caixa da bateria; nos cabos e terminais, a presença de partes do cabos descobertas, a existência de conexão firme e integridade dos terminais; nos faróis e lanternas, verificou-se a ocorrência de ferrugem aparente e trincas nos vidros; no alternador, bem como no motor de partida, observando a luz de alerta do sistema elétrico.

O trator avaliado deverá ser movimentado, de modo averiguar todos os itens relacionados com a transferência de potência para a parte rodante. A embreagem foi 
verificada sendo acionada e constatando a transmissão do movimento, se ocorre a existência de vibrações, trepidações ou deslizamento, se há disjunção entre o motor e os órgãos de transmissão, se o acionamento ocorre com mínimo esforço, tanto para embrear como para desembrear. Foi averiguada a performance da caixa de câmbio na situação em que o trator inicialmente necessita de maior torque e baixa rotação e esta operação pode ser feita também em sentido contrário, marcha ré: observação de ruídos, perda de força tratória e ganho de velocidade, perda de velocidade e ganho de torque e solavancos. O diferencial necessita que o trator, em movimento, faça curvas para ambos os lados, invertendo a direção do giro, a afim de que as engrenagens componentes do diferencial possam efetuar movimentos que vão exigir acionamento alternado de suas engrenagens e, em caso de danos, a presença de ruídos existentes.

Na tomada de potência foi observado o entalhe, se a haste está alinhada e a presença de soldas no alojamento. Os freios foram avaliados, segundo a eficácia, colocando-se o trator em movimento, inicialmente, a baixa velocidade e em seguida procedia-se à ativação do freio, avaliando o tempo de resposta e a distância da frenagem.

A avaliação dos pneus dianteiros foi efetuada em comparação com o novo (tomado como referencial de 100\%), analisando-se o desgaste da banda de rodagem, a existência de ranhuras e fissuras área de contato com o solo e também no flanco (parte externa do pneu, que liga a banda de rodagem ao talão). Nos pneus traseiros foi requerida a análise das garras, como no item dianteiro procedendo a diminuição da nota conforme o desgaste. Para o eixo dianteiro foi efetuada a análise do movimento (a direção era girada de um extremo ao outro), verificando o raio de giro e a resposta da direção, se ocorria na exposição de folga ou ruídos que demonstrariam avarias no eixo e cubo. As rodas traseiras e dianteiras foram avaliadas levando-s em conta o aspecto e verificando se há ocorrência de ferrugem, danos na estrutura da roda e o estado dos parafusos de fixação e do cubo.

As notas atribuídas a cada item, de cada grupo, para cada trator, foram somadas por grupo, determinando sua média. Posteriormente, as médias obtidas por grupo foram novamente totalizadas e a média da nota dos grupos foi determinada. Esse procedimento gerou notas com casas decimais, mas como os indicadores são números 
inteiros, as notas tiveram que ser ajustadas. Foi adotado o seguinte critério para o ajuste: as notas que obtiveram decimais inferiores a 0.75 permaneceram na mesma classificação, já as iguais ou maiores foram elevadas ao limite imediatamente superior.

\subsection{Tratamento e análise dos dados,}

A estatística descritiva envolve o conjunto de dados coletados. A apresentação e caracterização, de modo a descrever apropriadamente as várias características desse conjunto (Levine, 2000). Para caracterizar a posição central e a dispersão dos dados utiliza-se uma das seguintes medidas: média aritmética, mediana ou moda, sendo que esse trabalho utilizou a média. Para determinar como os dados são distribuídos em torno da média utiliza-se o desvio padrão e a variância.

Foi feita a análise de regressão com o objetivo de prever os valores de uma variável dependente, com base nos valores de uma variável independente ou explicativa a regressão linear tem por objetivo avaliar a qualidade do ajuste da reta aos pontos observados e seu valor fornece a proporção da variação total de uma variável, explicada por outra variável através da função ajustada.

\subsection{Modelos adotados para comparação}

A depreciação, segundo a proposta da ASAE (1999) é considerada como uma parcela do custo fixo. A metodologia de cálculo empregada envolve a determinação da depreciação pelos métodos da linha reta, saldo decrescente, soma do dígito dos anos, fundo de recuperação de capital e valor de mercado.

\subsubsection{Método da Linha Reta ou Linear}


É o método da linha reta, onde o valor da máquina é depreciado de um valor constante dado pela equação (7).

$$
\mathrm{D}=\frac{(P-S)}{V}
$$

onde: $\mathrm{D}=$ depreciação.

$\mathrm{P}=$ preço de aquisição do equipamento.

$\mathrm{S}=$ valor de sucata ou revenda

$\mathrm{V}$ = vida econômica, em períodos de tempo

\subsubsection{Método do Saldo Decrescente}

O Método do saldo decrescente utiliza uma taxa constante de depreciação aplicada sobre o valor residual do ano anterior, sendo apresentado nas equações (8), (9) e (10).

$$
\begin{aligned}
& \mathrm{Dt}=B \cdot(1-d)^{\mathrm{t}-1} \cdot \mathrm{d} \\
& \mathrm{VRt}=\mathrm{B} \cdot(1-d)^{\mathrm{t}} \\
& \mathrm{d}=1-\left(\frac{V r n}{B}\right)^{1 / n}
\end{aligned}
$$

onde: $\mathrm{Dt}=$ depreciação no período $\mathrm{t}$. $\mathrm{B}$ = preço de aquisição ou base depreciável. 
$\mathrm{d}=$ taxa de depreciação.

$\mathrm{VR}=$ valor residual.

n = número que representa a idade da máquina em anos.

\subsubsection{Método Soma dos Dígitos dos Anos}

No Método da soma dos dígitos dos anos a taxa de depreciação é decrescente, mas se aplica ao mesmo valor, como no método linear. Assim, a taxa de depreciação e o valor residual decrescem à medida que o bem vai se depreciando. A equação 11 mostra como é calculada a depreciação através desse método.

$$
\text { Dn }=\left(\frac{N}{F}\right) \times(P-S)
$$

onde: Dn = taxa de depreciação no período $n$.

$\mathrm{N}$ = período ou ano corrente para o cálculo.

$\mathrm{F}$ = soma do digito naturais dos n períodos de vida útil.

$\mathrm{P}=$ preço de aquisição.

$\mathrm{S}=$ valor de revenda ou sucata.

\subsubsection{Método Fundo de Recuperação de Capital}

No método do fundo de recuperação de capital, o cálculo da depreciação é feito de forma a constituir uma reserva, sobre a qual incidem juros e assim reunir capital suficiente para a reposição do bem no final da vida útil. A equação (12) apresenta o cálculo para esse método: 


$$
\mathrm{Vn}=(P-S) \times\left[\frac{(1+i)^{L}-(1+i)^{n}}{(1+i)-1}\right]+\mathrm{S}
$$

onde: $\mathrm{Vn}=$ valor da reserva no ano $\mathrm{n}$.

$\mathrm{P}=$ custo de aquisição do equipamento.

$\mathrm{S}=$ valor de revenda ou sucata.

$\mathrm{i}=$ taxa de juros do período, normalmente anual.

$\mathrm{L}$ = ano corrente para o cálculo, ano n.

\subsubsection{Valores dos tratores usados com base no "O Estado de São Paulo"}

Foi utilizado neste trabalho o preço de tratores usados publicado pelo jornal "O Estado de São Paulo” (OESP), uma referência comumente utilizada como parâmetro em preços de tratores usados.

A publicação de uma tabela com preços de tratores usados, coletados no interior do estado de São Paulo pelo OESP é um referencial do mercado de tratores usados, sendo a fonte preferencial para este tipo de informação. Os valores utilizados neste trabalho foram extraídos OESP de 06 de agosto de 2003. 


\section{RESULTADOS E DISCUSSÃO}

\subsection{Questionário}

Como resultado da pesquisa, o questionário foi aplicado para todos os tratores. Devido à sua clareza, não ocasionou nenhuma dúvida quanto ao preenchimento e aos itens que deveriam ser avaliados. A aplicação mostrou-se rápida e objetiva, com a análise do estado de conservação da maquinaria tornando-se útil. O questionário desenvolvido demonstra consistência e confiabilidade.

\begin{tabular}{|c|c|c|c|c|c|}
\hline Motor & & & & & \\
\hline Correias & 1 & 2 & 3 & 4 & 5 \\
\hline Tanque de Combustível & 1 & 2 & 3 & 4 & 5 \\
\hline Sistema de Injeção e Filtros & 1 & 2 & 3 & 4 & 5 \\
\hline Purificador de Ar e Mangueiras & 1 & 2 & 3 & 4 & 5 \\
\hline Radiador e Mangueiras & 1 & 2 & 3 & 4 & 5 \\
\hline Carter & 1 & 2 & 3 & 4 & 5 \\
\hline Vazamentos de Óleo & 1 & 2 & 3 & 4 & 5 \\
\hline Coletor, Escape e Silencioso & 1 & 2 & 3 & 4 & 5 \\
\hline Bomba d Água & 1 & 2 & 3 & 4 & 5 \\
\hline Ruídos do Motor & 1 & 2 & 3 & 4 & 5 \\
\hline
\end{tabular}

Figura 7- Secção do questionário que descrimina o grupo motor

A Figura 7 demonstra a forma utilizada para o preenchimento do estado de conservação de cada item. A íntegra do questionário encontra-se no anexo. 
É importante ressaltar que somente quatorze concessionários acessaram o formulário virtual e participaram da pesquisa, sendo cadastrado vinte e oito de tratores, perfazendo 3\% dos concessionários existentes no país. Devido ao baixo índice de resposta, a pesquisa foi concentrada na região circunvizinha de Piracicaba-SP, em um raio de $150 \mathrm{~km}$. Nesse levantamento foram objeto da pesquisa os 26 (vinte e seis) concessionários da região (relação em anexo) e os revendedores autônomos. A coleta foi feita nos meses de julho e agosto de 2003 e os resultados da pesquisa são demonstrados na Tabela 5.

Tabela 5. Descrição da fonte de dados

\begin{tabular}{lcccc}
\hline & $\begin{array}{c}\text { Faixa de potência } \\
\text { de } \mathbf{3 7 . 8 0} \mathbf{a}\end{array}$ & $\begin{array}{c}\text { Faixa de potência } \\
\text { de } \mathbf{7 5 . 6 0 - 1 5 0 . 4 4} \\
\mathbf{k W}\end{array}$ & Total & Porcentagem \\
Fonte de dados & $\mathbf{7 4 . 8 4 \mathbf { k W }}$ & & & \\
\hline Página na & & 20 & 28 & 14 \\
Internet & 8 & 53 & 175 & 86 \\
Coleta na região & 122 & 73 & 203 & 100 \\
Total & 130 & & & \\
\hline
\end{tabular}

Devido ao acesso ao questionário, não houve como identificar as concessionárias participantes, somente sua localização geográfica, cidade e estado, e o código IP (número do computador que efetuou o acesso). Dessa forma, as informações aqui apresentadas não possuem nenhuma forma de identificação individual, de marca, fabricante ou nome do concessionário. A Tabela 6 mostra a participação dos concessionários por cidade e estado, sendo que os acessos ocorreram de forma dispersa, com um maior número de participantes, via Internet, na região sudeste (17 acessos), a região sul teve 6 acessos, a região centro-oeste acessou 2 vezes, a região nordeste registrou 1 único acesso e o Distrito Federal teve 2 acessos. 
Tabela 6. Cidade e estado dos revendedores participantes

\begin{tabular}{lcc}
\hline Cidade & Estado & Quantidade em acessos \\
\hline Maringá & PR & 1 \\
Palotina & PR & 2 \\
Campos Novos & SC & 1 \\
Mafra & SC & 2 \\
Unaí & MG & 1 \\
Janauba & MG & 1 \\
Uberaba & MG & 5 \\
Uberlândia & MG & 10 \\
Sapezal & MT & 1 \\
Maracaju & MS & 1 \\
Brasília & DF & 2 \\
Salvador & BA & 1 \\
\hline
\end{tabular}

\subsection{Análise descritiva dos resultados}

\subsubsection{Faixa de potência}

A fim de examinar as potências encontradas, devemos separar os tratores em duas faixas, a primeira de 37,80 a $74,84 \mathrm{~kW}$ e a outra de 75,60 a 150,44 kW, o sistema métrico internacional utiliza a unidade quilo-watt $(\mathrm{kw})$ para a mensuração de potência. Para efeito de análise, deve-se separar, novamente, em faixas de 6,80 kW, ou seja, de 37,80 - 44,60 kW, 45,36 - 52,16 kW, 52,92 - 59,72 kW, 60,48 - 67,28 kW e 68,04 74,84 kW. A Figura 8 apresenta a distribuição das faixas de potência dentro do segmento de 37,80 a $74,84 \mathrm{~kW}$.

A faixa de 37,80 - 44,60 kW apresenta um percentual elevado desses tratores, aproximadamente $14 \%$ dos dados coletados. Essa concentração pode ser demonstrada pela sua participação, aproximadamente 10\% (9,92\%), e se deve à ampla gama de operações que eles podem desenvolver em propriedades agrícolas de diferentes tamanhos e também por estarem situadas logo acima do limite da faixa de 0 a 37,64 kW. 


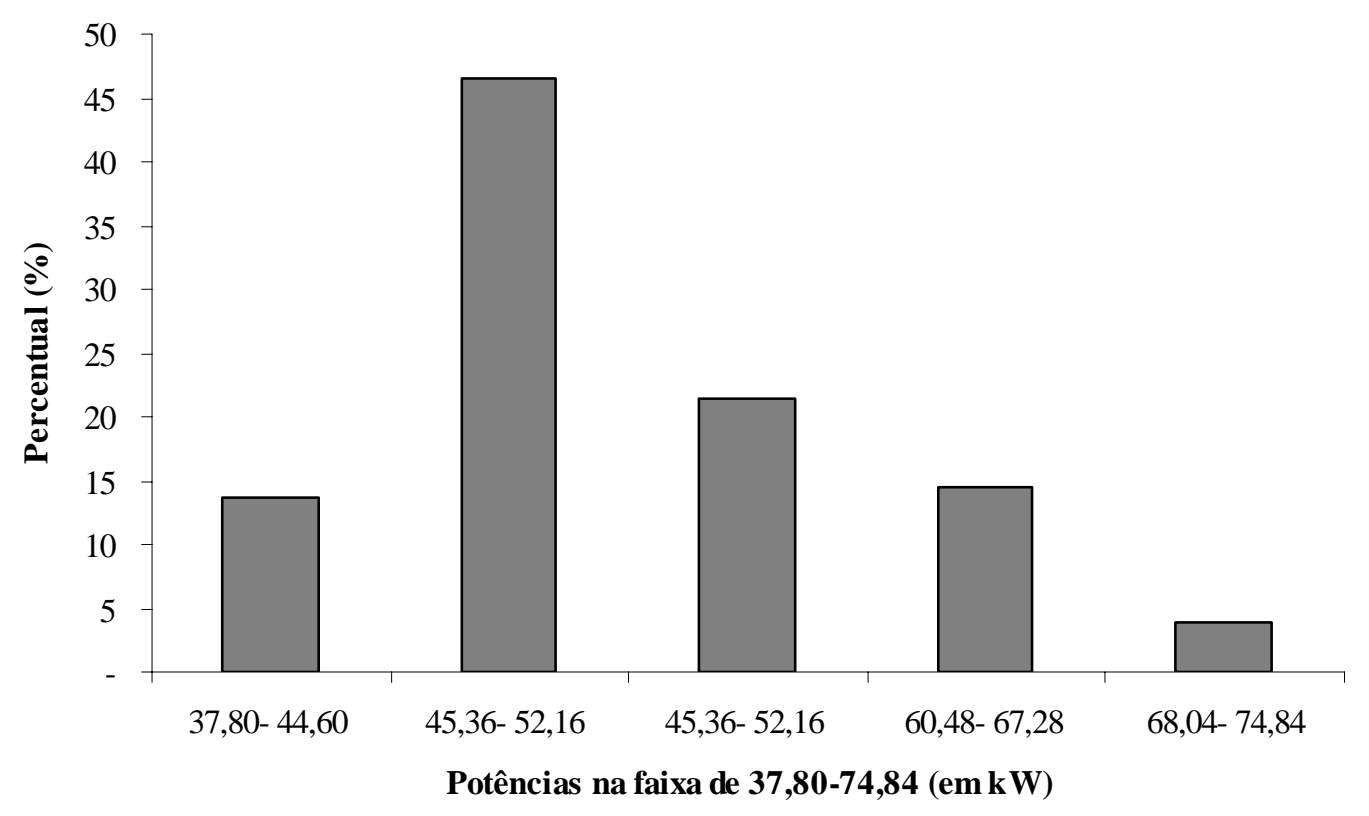

Figura 8 - A distribuição percentual de tratores de 37,80 a 74,84 kW

Há ocorrência de exemplares analisados, com potência de 37,80 kW, e mesmo com potencial reduzido, que figuram na $4^{\mathrm{a}}$ posição em número de tratores coletados. A faixa de potência que compreende esses tratores caracteriza-se pela concorrência acirrada entre os fabricantes, devido ao grande número de consumidores potenciais.

Os modelos encontrados na categoria de 45,36 - 52,16 kW estão concentrados nos tratores com potência de 49,14 kW, representando 25\% dos tratores coletados. Essa concentração pode ser explicada pela necessidade do mercado em obter maquinaria que possua variedade de aplicações. Observa-se na Figura 9 que o limite imediatamente superior a 37,80 - 44,60 kW possui um percentual elevado de tratores, como na categoria inferior.

Na categoria de 52,92 - 59,72 kW não há variedade de modelos com potências diversas, como nas demais, são encontrados tratores somente com potência de 56,70 $\mathrm{kW}$. O percentual encontrado é de $21,37 \%$, dos tratores coletados neste trabalho. Com esse percentual, somado ao de $49,14 \mathrm{~kW}$, obtém-se um percentual de $46 \%$ dos tratores coletados, isto pode significar uma tendência do mercado em adquirir máquinas com 
potência de 49,14 kW e 56,70 kW, pelo menos na região onde ocorreu à coleta.

Para os tratores com potência imediatamente acima de 56,70 kW, situados na categoria de 60,48 - 67,28 kW, constata-se percentual relativamente expressivo (14,5\% dos dados coletados). Os modelos de $60,48 \mathrm{~kW}$ respondem por 7,60\% dos tratores e, a partir dessa potência, os valores diminuem sensivelmente, reduzindo-se a 3,82 \% para os de 64,26 kW e 3,05\% para tratores com 65,01 kW.

Na categoria de potência de 68,04 - 74,84 kW, o percentual encontrado é $3,82 \%$. A classe possui o equivalente a $50 \%$ do número de tratores da categoria anterior e os percentuais demonstram uma queda acentuada, reduzem-se a 1,5\% e 2,3\% dos tratores de 68,04 kW e, respectivamente. Como esses tratores encontram-se muito próximos da faixa de 75,60-150,44 kW, o fato pode ser explicado pela preferência em adquirir maquinaria mais potente destinada a operações especificas.

A metodologia para análise do segmento de tratores com faixa de potência de 75,60 a 150,44 kW, será a mesma utilizada nos tratores de 37,80 a 74,84 kW. A subdivisão da categoria 75,60- 150,44 kW: 75,60- 82,40 kW, 83,16- 89,96 kW, 90,7297,52 kW, 98,28- 105,08 kW, 105,84- 112,64 kW, 113,40- 120,20 kW, 120,96- 127,76 kW, 128,52- 135,32 kW, 136,08- 142,88 kW, 143, 64- 150,44 kW. Nota-se variedade em relação às potências encontradas, não sendo detectada nenhuma tendência de concentração em determinada potência. Na categoria de 75,60- 150,44 kW existe um maior número de faixas de potência e, nessas faixas, maior variedade de modelos. Os dados referentes a essas potências se encontram na Figura 9.

A categoria de 75,60- 82,40 kW apresenta a maior diversidade de potência em relação a outras categorias, apresentando tratores de 75,60, 76,35, 77,86 e 79,30 kW. Os tratores com potência entre 75,60- 82,40 kW representam 30\% dos tratores coletados, notando-se um agrupamento maior de espécimes com até 79,30 kW. Esse fato, possivelmente, está ligado à necessidade de maior potência tratória. Cabe ressaltar, ainda, que essa faixa possui potência 50\% maior do que o segmento de 49,14- 56,70 kW. Talvez isso deva ser levado em consideração, uma vez que o trator dessa potência pode complementar a necessidade de distintas potências na atividade agrícola dentro de uma mesma propriedade rural. 


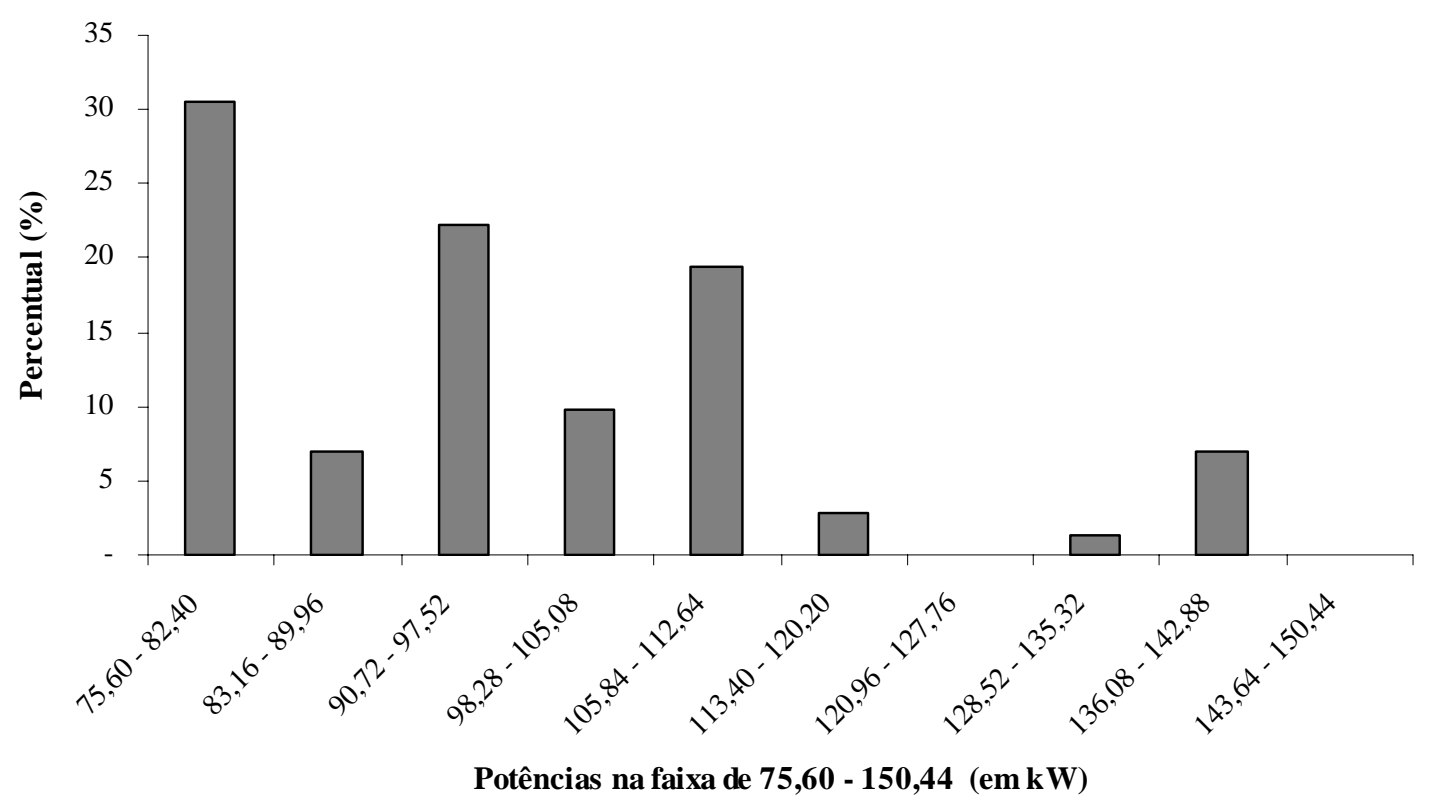

Figura 9- As potências fabricadas de 75,60 - 150,44 kW

Na classificação de 83,16 a 89,96 kW, o percentual encontrado de tratores foi de aproximadamente 7\%, percentual razoável, porém reduzido, se comparado com o de 75,60 - 82,40 kW. Analisando o percentual constatamos que 1,39\% são de tratores com 75,60 kW e o restante 5,56\% representa os tratores com 89,20 kW.

Na categoria de 90,72 - 97,52 kW apresentam-se somente duas potências, 92,98 kW e de 95,25 kW. Apesar de somente serem encontradas essas duas potências, a classe responde por 22,22\% dos tratores coletados e o número de exemplares pode ser observado na Tabela 7. 
Tabela 7. Potência, faixas de potência, unidades

\begin{tabular}{lcc}
\hline $\begin{array}{c}\text { Potência } \\
(\mathbf{k W})\end{array}$ & $\begin{array}{c}\text { Faixa de potência } \\
(\mathbf{k W})\end{array}$ & Unidades \\
\hline $\mathbf{7 5 , 6 0} \mathbf{~ k W}$ & $75,60-82,40 \mathrm{~kW}$ & 5 \\
$\mathbf{7 6 , 3 5 k W}$ & $75,60-82,40 \mathrm{~kW}$ & 1 \\
$\mathbf{7 7 , 8 6} \mathbf{~ k W}$ & $75,60-82,40 \mathrm{~kW}$ & 5 \\
$\mathbf{7 9 , 3 0 k W}$ & $75,60-82,40 \mathrm{~kW}$ & 11 \\
$\mathbf{8 3 , 1 6} \mathbf{~ k W}$ & $83,16-89,96 \mathrm{~kW}$ & 1 \\
$\mathbf{8 9 , 2 0} \mathbf{~ k W}$ & $83,16-89,96 \mathrm{~kW}$ & 4 \\
$\mathbf{9 2 , 9 8} \mathbf{~ k W}$ & $90,72-97,52 \mathrm{~kW}$ & 8 \\
$\mathbf{9 5 , 2 5} \mathbf{~ k W}$ & $90,72-97,52 \mathrm{~kW}$ & 8 \\
$\mathbf{9 8 , 2 8} \mathbf{~ k W}$ & $98,28-105,08 \mathrm{~kW}$ & 4 \\
$\mathbf{1 0 4 , 3 2} \mathbf{~ k W}$ & $98,28-105,08 \mathrm{~kW}$ & 3 \\
$\mathbf{1 0 5 , 8 4} \mathbf{~ k W}$ & $105,84-112,64 \mathrm{~kW}$ & 11 \\
$\mathbf{1 0 9 , 6 2} \mathbf{~ k W}$ & $105,84-112,64 \mathrm{~kW}$ & 3 \\
$\mathbf{1 1 3 , 4 0} \mathbf{~ k W}$ & $113,40-120,20 \mathrm{~kW}$ & 2 \\
$\mathbf{1 3 0 , 7 8} \mathbf{~ k W}$ & $128,52-135,32 \mathrm{~kW}$ & 1 \\
$\mathbf{1 3 6 , 0 8 ~ k W}$ & $136,08-142,88 \mathrm{~kW}$ & 5 \\
\hline
\end{tabular}

Na classe de 98,28 -105,08 kW é possível notar um agrupamento de potências na categoria de 105,84 kW (11 unidades), com queda nas categorias posteriores. Os dados coletados concentram-se nos segmentos de 75,60 - 82,40 kW, 90,72 - 97,52 kW e 105,84 - 112,64 kW, dispersando-se nos demais segmentos.

A seleção de força tratória deve-se à exigência e à especificidade do tipo de cultura, propriedade e implemento utilizado em cada operação agrícola. Uma vez que esses tratores têm elevado custo de aquisição, justifica-se seu uso para condições especificas, caso contrário torna-se economicamente inviável a sua propriedade.

\subsubsection{Vida útil}

A vida útil dos tratores coletados nesse trabalho foi dividida em três períodos. O primeiro período foi composto por tratores com vida útil de 0 a 5 anos, no segundo as máquinas de 5 a 10 anos e em terceiro o maquinário com mais de 10 anos. Essa 
classificação baseou-se na vida útil de 10 anos (IEA). Portanto de 0 a 5 anos $50 \%$ da vida útil, de 5 a 10 anos final da vida útil, e acima de 10 anos. Os tratores de idade entre 5 e 10 anos estão desigualmente representados. Notadamente, há maior ocorrência de tratores com vida útil de 8, 9 e 10 anos, conforme pode ser observado na Figura 11. Essa tendência, possivelmente, está associada à utilização do trator até o final de sua vida útil, contábil ou econômica, sendo o mesmo colocado à venda para efetuar a renovação da frota.

Os tratores com mais de 10 anos de idade coletados neste trabalho apresentaram-se desigualmente representados. O número de tratores com mais de 10 anos supera os de 0 a 5 anos e os de 5 a 10 anos.

A classificação engloba, neste caso, tratores de 11 a 34 anos, sendo que o maior agrupamento do número de tratores no segmento está entre 26 e 31 anos. A presença de tratores de idade avançada na pesquisa, possivelmente esta relacionada à demanda por tratores e à facilidade na obtenção de crédito para modernização da agricultura, isto apesar das estimativas de vida útil em 10 anos.

Os trabalhos de Hansen (1990), Perry (1995) e Cross (1996) foram baseados em frotas de tratores a venda em leilões, sendo considerados aqueles com até 20 anos de idade.

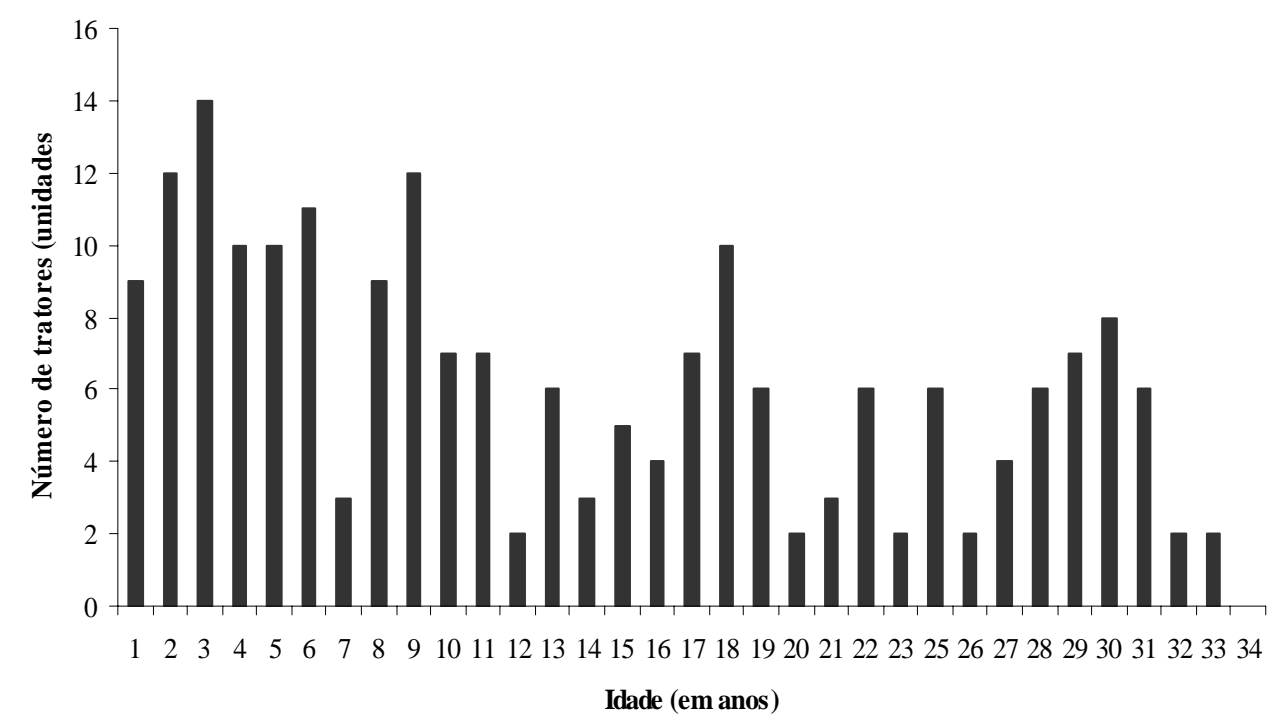

Figura 10- Freqüência da idade dos tratores coletados 


\subsubsection{Estado de conservação}

A maquinaria foi analisada segundo seu estado de conservação que varia acentuadamente. Para fins de análise, os tratores são separados de acordo com a condição (ruim, regular, boa, muito boa, ótima), conforme a vida útil em períodos que vão de 0 a 5 anos de idade, 5 a 10 anos e tratores com mais de 10 anos.

No período de 0 a 5 anos foram encontrados tratores em condições que variavam de regular (nota 2) a ótima (nota 5), sendo 76\% dos tratores classificados como muito bom ou ótimo, resultado já esperado, uma vez que maquinaria nova ou semi nova contém inovações tecnológicas que permitem um melhor aproveitamento do esforço tratório com desgaste mínimo e, em se tratando de maquinaria agrícola, nesse período inicial se verifica a plena capacidade produtiva.

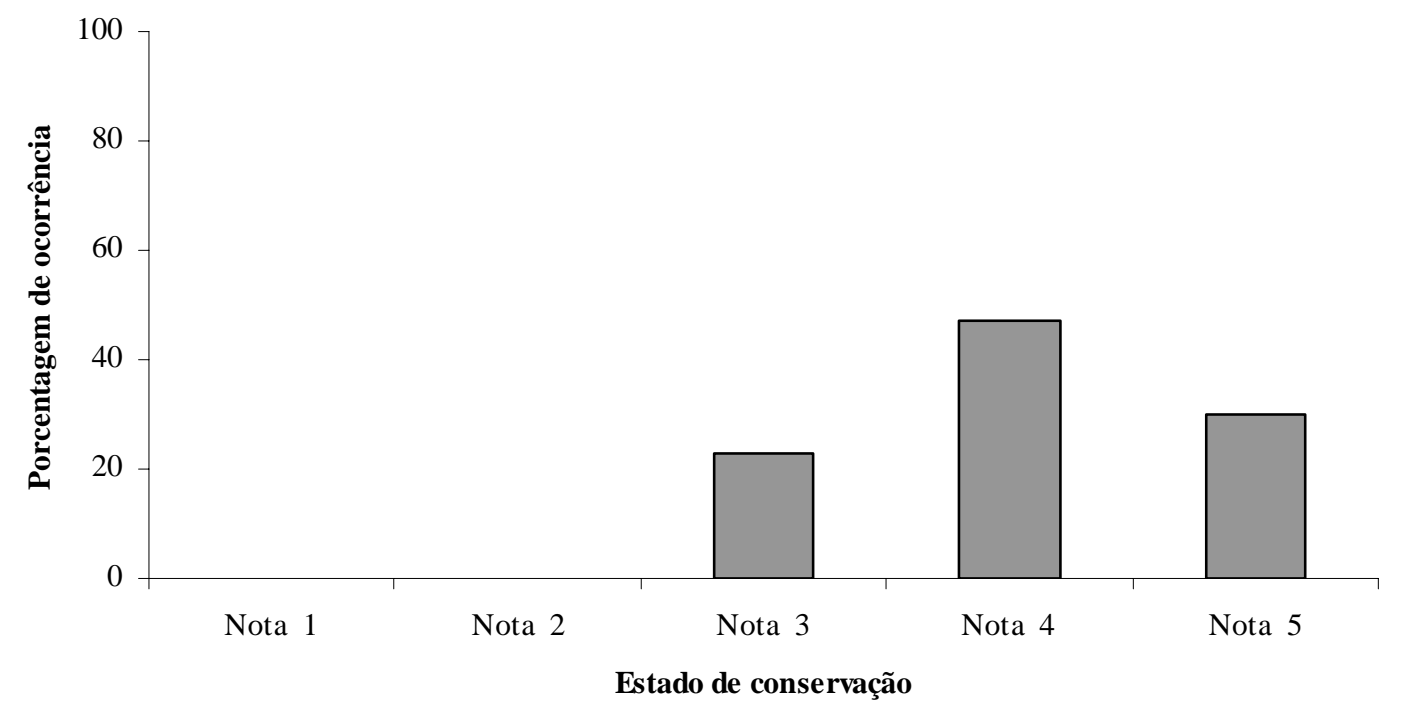

Figura 11- Estado de conservação encontrado em tratores com idade 0 a 5 anos

Sendo estimada a vida útil em 10 anos, conseqüentemente nesse período (0-5 anos) a máquina dispõe da metade de sua vida útil, estando apta a desenvolver todo tipo de serviço sem que seja necessária manutenção dispendiosa, a não ser a básica, como troca de óleo e filtros. O percentual de $2 \%$ encontrado com nota 2 (regular) permite 
considerar as máquinas como intensivamente utilizadas e colocadas à venda para renovação da frota ou sucateadas.

O período de uso compreendido entre 5 e 10 anos mostrou uma ampliação do percentual de notas 2 (regular), o desaparecimento de tratores com nota 5 (ótima) e também uma diminuição dos tratores em estado de conservação muito boa (nota 4) juntamente com uma ampliação do percentual de tratores em bom estado (nota 3). A observação da figura 12 pode constatar isto.

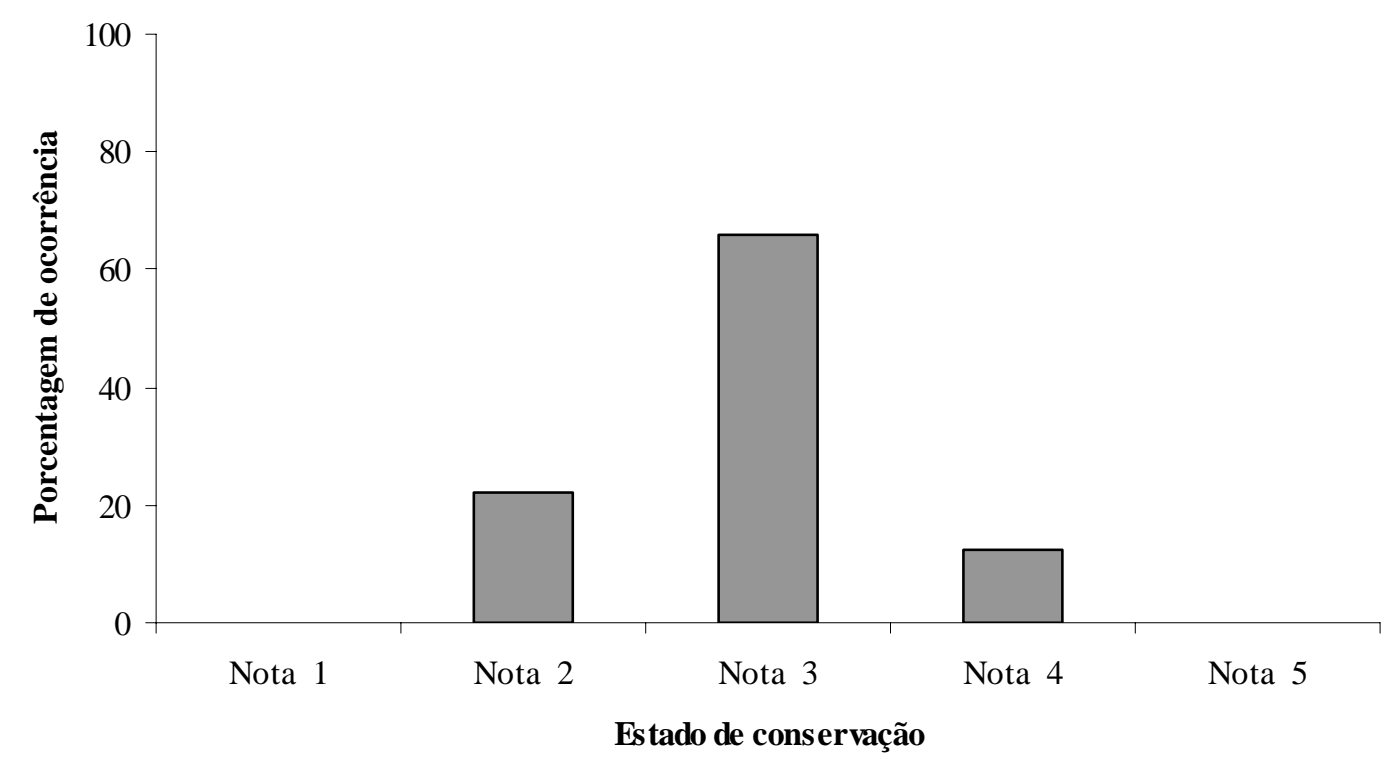

Figura 12 - Estado de conservação em tratores com idade de 5 até 10 anos

Dessa maneira podemos inferir que os tratores avaliados, com idade superior a 5 anos e inferior a 10, mostraram diminuição na qualidade do estado de conservação, não sendo encontrados tratores com nota 5, além do aumento significativo de notas 2, ( que passou de $2 \%$ para $12 \%$ ) e 3 ( que evoluiu consideravelmente de $22 \%$ para $66 \%$ ). Ao contrário, o percentual de tratores com nota 4 diminuiu de 46\% para 12\%. Constatase que, com o avanço da idade do trator agrícola a condição do estado de conservação deteriora possivelmente em função do desgaste e exaustão. Em se tratando de máquinas agrícolas é esperado que a capacidade de exercer esforço tratório diminua com o passar do tempo e seu estado de conservação venha a ser comprometido. 
Os tratores coletados com mais de 10 anos de idade apresentaram aumento do estado de conservação com nota 1 (estado ruim), representando 6\% do total da maquinaria. Nessa idade, o aparecimento de nota 1 contrasta com os períodos anteriores, onde não se apresenta, ocorreu uma diminuição dos tratores em boas condições (de 66\% para 59\%), e aumento de tratores com estado regular (de 22\% para 27\%) em aproximadamente um terço dos tratores analisados. A maquinaria considerada muito boa, apesar da retração em seus percentuais, ainda ocorre em 8\% dos dados coletados.

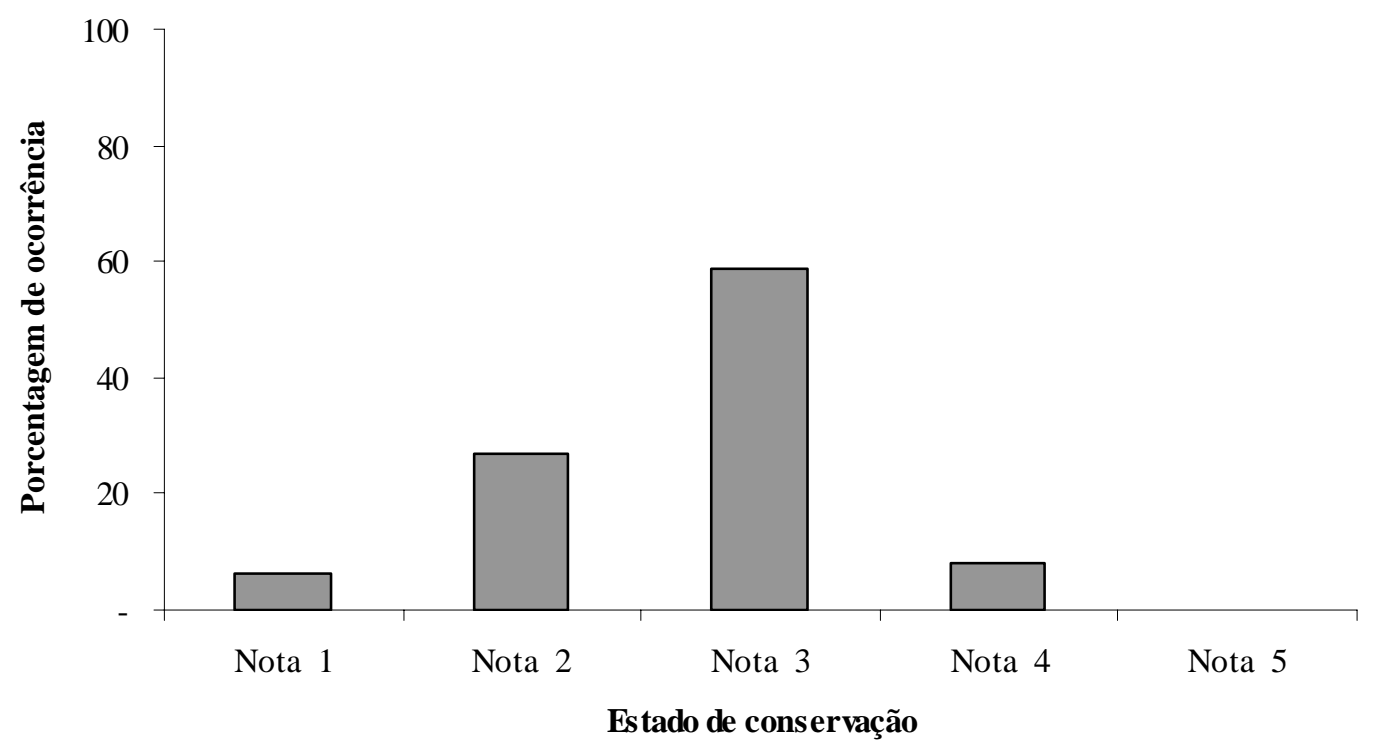

Figura 13 - Estado de conservação de tratores com mais de 10 anos

Embora apresentem percentuais elevados de tratores em condições regular e ruim, a maioria das máquinas analisadas possui condição boa ou muito boa (67 \%). Isto provavelmente se relaciona à necessidade de apresentar ao mercado uma maquinaria que não implique em gastos elevados com manutenção no período imediatamente posterior à aquisição do trator usado, o que descaracterizaria o preço pago, acarretando prejuízo ao comprador. O resultado ainda demonstra a extensa vida útil e a durabilidade da maquinaria. Embora a vida útil seja estimada em 10 anos para fins de orçamento e cálculo de custo, encontramos nesta pesquisa espécies com até 34 anos. A maquinaria agrícola é a principal força tratória na agricultura, conseqüentemente se não estiver em 
condição de executar as operações requeridas, com eficiência e custo baixo, compromete as funções para as quais se destina.

\subsubsection{Horas trabalhadas}

Quanto à quantidade de horas trabalhadas, há a necessidade de se fazer ressalvas, pois, pela idade de alguns exemplares coletados, não era confiável assumir o registro do horímetro. Também eram comuns casos em que o horímetro estava danificado, parado ou sem condições de leitura.

A quantidade de horas trabalhadas / estimadas encontradas no trabalho oscilou em demasia, ocorrendo casos em que o trator foi colocado à venda com menos de 1000 horas de uso, podendo ser considerado, pela baixa quantidade de horas de trabalho na faixa de potência de 75,60 -150,44 kW, como novo. Como houveram casos em que o trator mostrava o horímetro danificado ou com a quantidade de horas irreais, esta ocorrência era descartada, podendo o valor estar abaixo da real quantidade de horas trabalhadas. O resultado obtido com a análise descritiva dos dados pode ser observado na Tabela 8.

Tabela 8. Estatística descritiva de horas trabalhadas

\begin{tabular}{llllllll}
\hline Variável & & \multicolumn{7}{c}{ Estatística } \\
\hline & Média & Mediana & $\begin{array}{l}\text { Desvio } \\
\text { padrão }\end{array}$ & Assim. & Curtose & $\begin{array}{l}\text { Erro } \\
\text { padrão }\end{array}$ & Variância \\
\hline $\begin{array}{l}\text { Horas } \\
\text { Trabalhadas }\end{array}$ & 6.263 & 6.000 & 3.618 & 0,33 & 0,43 & 253 & $\begin{array}{l}13.095 .53 \\
9\end{array}$ \\
\hline
\end{tabular}

A elevada média de horas trabalhadas deve-se, sobretudo, à idade da frota, ponderada em 13 anos. Considerando um uso anual, sugerido pela ASAE de 800 horas de uso anual, teremos um exemplar de 13 anos com 10.400 horas estimadas, valor que está bem acima da média de horas trabalhadas. A estimativa de horas baseadas na 
proposta da ASAE corrobora o desvio padrão obtido, uma vez que pode haver uma variação para cima ou para baixo. A elevada variância apresentada na tabela expressa a variabilidade dos dados de uma frota que possui extremos: de tratores com 700 horas de uso até exemplares com 12.000 horas estimadas.

\section{3- Depreciação}

\subsubsection{Análise}

Os dados obtidos de 203 tratores, observados no intervalo de 1 a 34 anos, foram agrupados em um único conjunto para fins de análise. A partir dos dados foram ajustados os modelos de regressão (Tabela 9) pelos mínimos quadrados: idade e preço de mercado (Premer); idade e horas trabalhadas (Htrab); idade e estado de conservação (Est); horas trabalhadas e estado de conservação; horas trabalhadas e preço de mercado. Os resultados são apresentados na Tabela 9:

Tabela 9. Análise de regressão

\begin{tabular}{lccc}
\hline $\begin{array}{l}\text { Análise } \\
\text { regressão }\end{array}$ & $\mathbf{R}^{2}$ & $\mathbf{R}$ & Teste $\mathbf{F}$ \\
\hline Idade x Prmer & 0,6154 & 0,7287 & $321,7177^{*}$ \\
Idade x H trab & 0,2884 & 0,5370 & $81,4741^{*}$ \\
Idade x Est & 0,3200 & 0,5657 & $94,6124^{*}$ \\
H trab x Est & 0,2539 & 0,5039 & $68,4081^{*}$ \\
H trab x Prmer & 0,1838 & 0,4287 & $45,2683^{*}$ \\
\hline
\end{tabular}

*Significativo a 5\% de probabilidade.

Todas as análises de regressão acima descritas foram significativas ao nível de $5 \%$ de probabilidade. Somente no coeficiente de determinação $\left(\mathrm{R}^{2}\right)$ entre o preço de 
mercado e a vida útil, apresentou o alto valor, preço de mercado (variável dependente) através de sua relação com a idade (variável independente). O resultado da análise de regressão em relação à idade com o preço encontrado foi também encontrado no trabalho de Perry (1995).

O estado de conservação da maquinaria não influenciou de maneira significativa a depreciação. Coss (1996) afirma que os tratores com melhor estado de conservação não obtiveram diferenciação no preço de mercado. Perry (1995) conclui que aproximadamente 55 \% dos tratores vendidos em leilões nos EUA estavam em condições consideradas como bom estado de conservação.

A Teste $\mathrm{f}$ com significativo (Probabilidade a 0,01) confirma a representação dos valores encontrados no mercado pela função.

\subsubsection{Modelo}

A função exponencial foi a que melhor ajustou para a certificação do modelo adotado, sendo a expressão apresentada na equação 13:

$$
\begin{aligned}
& Y=63,277 . \mathrm{e}^{-0,0465 X} \\
& \mathbf{R}^{\mathbf{2}}=\mathbf{0}, \mathbf{7 9 7}
\end{aligned}
$$

onde: $\mathrm{Y}=$ valor em percentual ( preço de mercado )

$$
\mathrm{X}=\text { idade do trator em anos }
$$




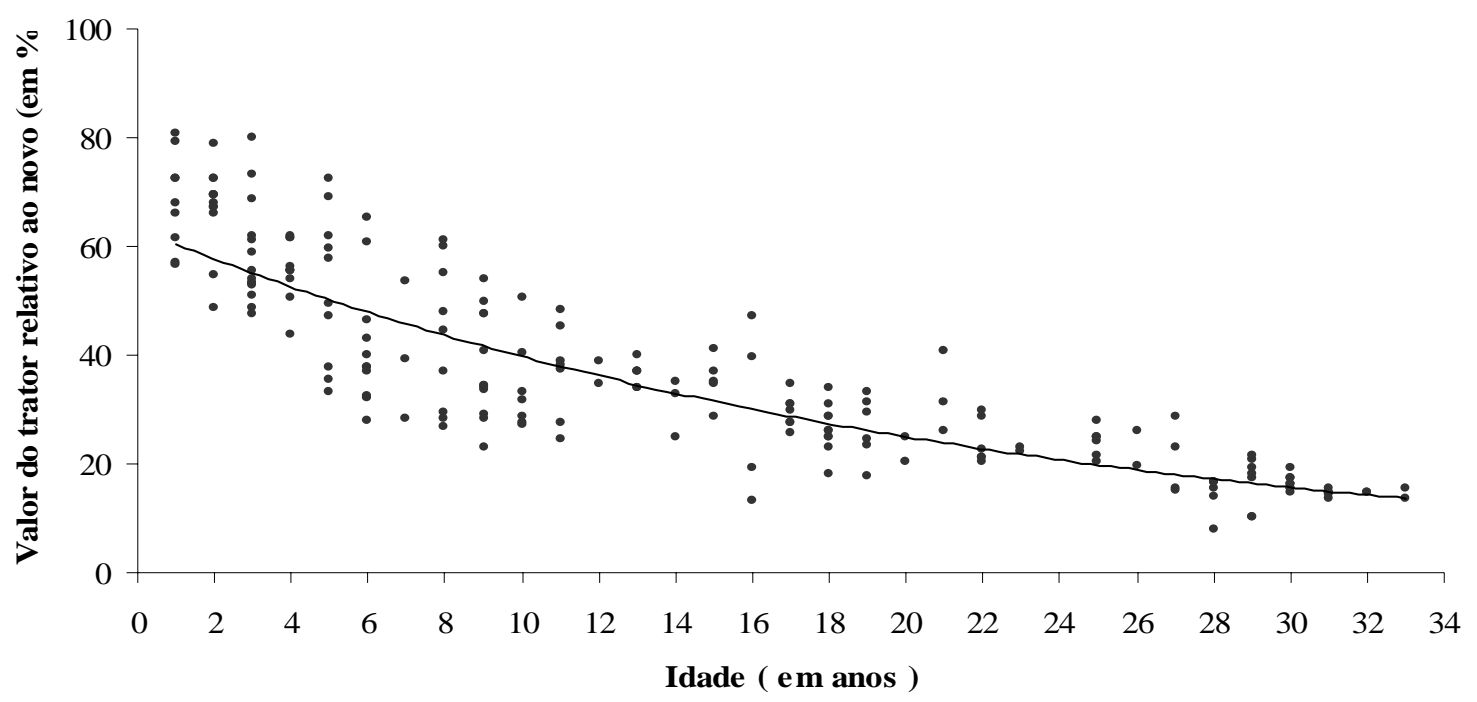

Figura 14 - Modelo determinado para predizer o valor de mercado de tratores agrícolas com mais de um ano de uso

A função obtida prediz o valor em percentual de tratores agrícolas de rodas com tração simples (4x2), assistida (4x2 TDA) e integral (4x4), potência de 37,80 a 74,84 kW e 75,60 a 150,44 kW, empregados em atividades agrícolas, válida para o intervalo de 1 a 34 anos.

\subsection{Comparação dos modelos propostos}

O ajuste do modelo empírico aos métodos propostos na bibliografia tem por finalidade verificar a realidade do mercado frente às estimativas. A efetiva comparação do modelo empírico com os modelos propostos na bibliografia e o jornal “O Estado de São Paulo”(OESP). O resultado em percentuais do valor residual pode ser observado na Tabela 10. 
Tabela 10. Ajuste do modelo empírico com os propostos na bibliografia

\begin{tabular}{ccccccccccccc}
\hline \multirow{2}{*}{ Ano } & \multicolumn{10}{c}{ Métodos de depreciação e o ajuste ao modelo empírico } \\
\cline { 2 - 13 } & Real & Linear & B-A & Saldo & C-A & Soma & D-A & Fundo & E-A & OESP & F-A \\
\hline $\mathbf{1}$ & 63 & 94 & 31 & 91 & 28 & 89 & 26 & 97 & 34 & 59,6 & $-3,4$ \\
$\mathbf{2}$ & 55,6 & 88 & 28,4 & 83 & 23,4 & 79 & 198,4 & 93 & 33,4 & 52,9 & 6,7 \\
$\mathbf{3}$ & 55,0 & 82 & 27 & 76 & 21 & 71 & 16 & 88 & 33 & 49 & -6 \\
$\mathbf{4}$ & 52,5 & 76 & 23,5 & 69 & 16,5 & 63 & 10,5 & 84 & 31,5 & 46,3 & $-6,2$ \\
$\mathbf{5}$ & 50,2 & 70 & 20,2 & 63 & 12,8 & 56 & 5,8 & 78 & 27,8 & 43,7 & $-6,5$ \\
$\mathbf{6}$ & 47,7 & 64 & 16,1 & 58 & 10,1 & 51 & 3,1 & 72 & 24,1 & 41 & $-6,9$ \\
$\mathbf{7}$ & 45,7 & 58 & 12,3 & 53 & 7,3 & 47 & 1,3 & 66 & 20,3 & 38,4 & $-7,3$ \\
$\mathbf{8}$ & 43,6 & 52 & 8,4 & 48 & 4,4 & 43 & $-0,6$ & 58 & 14,4 & 35,7 & $-7,9$ \\
$\mathbf{9}$ & 41,6 & 46 & 4,4 & 44 & 2,4 & 41 & $-0,6$ & 49 & 7,4 & 33,1 & $-8,5$ \\
$\mathbf{1 0}$ & 39,7 & 40 & 0,3 & 40 & 0 & 40 & 0 & 40 & 40 & 30,4 & $-9,3$ \\
\hline
\end{tabular}

O modelo empírico apresenta um percentual maior de redução no primeiro ano em relação ao método da soma dos dígitos dos anos e o valor mais baixo entre os constantes na bibliografia. Esta diferença se amplia quando comparada ao método de fundo de recuperação de capital. Em comparação com o percentual do jornal "O Estado de São Paulo”(OESP), o valor real apresenta uma pequena diferença de 3,4\%, mesmo sendo o valor coletado em revendas do interior do Estado de São Paulo.

O valor de abatimento no primeiro ano do modelo real, por estar relacionado com o preço de lista, não considera o desconto obtido em negociação para aquisição de maquinário, tomando como preço de aquisição o constante na tabela. Os demais métodos apresentam descontos que variam de 3 a 11\% e o modelo real o desconto de 37\%, porém os modelos propostos são baseados em estimativas de custo e orçamento e, desta maneira, não contemplam a venda do trator com um ano de uso.

Embora em relação ao ajuste do modelo real aos da bibliografia apresente diferenças no primeiro ano que variaram de 26 a 34\%. Esse percentual elevado de depreciação para o primeiro ano está relacionado a possíveis inovações tecnológicas incorporadas ao modelo novo, à garantia fornecida pela fábrica e ao risco em adquirir maquinário usado. 
No percentual de 30\% proposto por Molina et al.(1998), para a depreciação no primeiro ano de uso, nesse trabalho foi obtido um percentual superior ocorrendo uma diferença significativa de 7\%. Mesmo levando em consideração o período distinto entre as duas comparações, o primeiro foi marcado pelo congelamento de preços, em patamar elevado, sendo concedidos descontos progressivos, e o segundo por um aquecimento de vendas por influência do MODERFROTA.

No quinto ano a diferença entre o modelo real e os propostos diminuiu sensivelmente, reduzindo 11 pontos percentuais em relação ao linear, aproximadamente $16 \%$ ao saldo decrescente, $20 \%$ à soma dos dígitos dos anos e somente $7 \%$ ao fundo de recuperação do capital. Neste caso cabe ressaltar que este método inclui indexação do saldo remanescente. O método da soma dos dígitos dos anos fica próximo ao real, com uma diferença de $5 \%$.

A partir do quinto ano as diferenças tornam-se menores, sendo que o modelo da soma dos dígitos apresenta no oitavo ano uma equiparação com o modelo real. Os demais métodos mantêm sua redução até chegar ao valor de sucata ou descarte de $40 \%$ do maquinário, sendo o fundo o que sofre maiores reduções em termos percentuais.

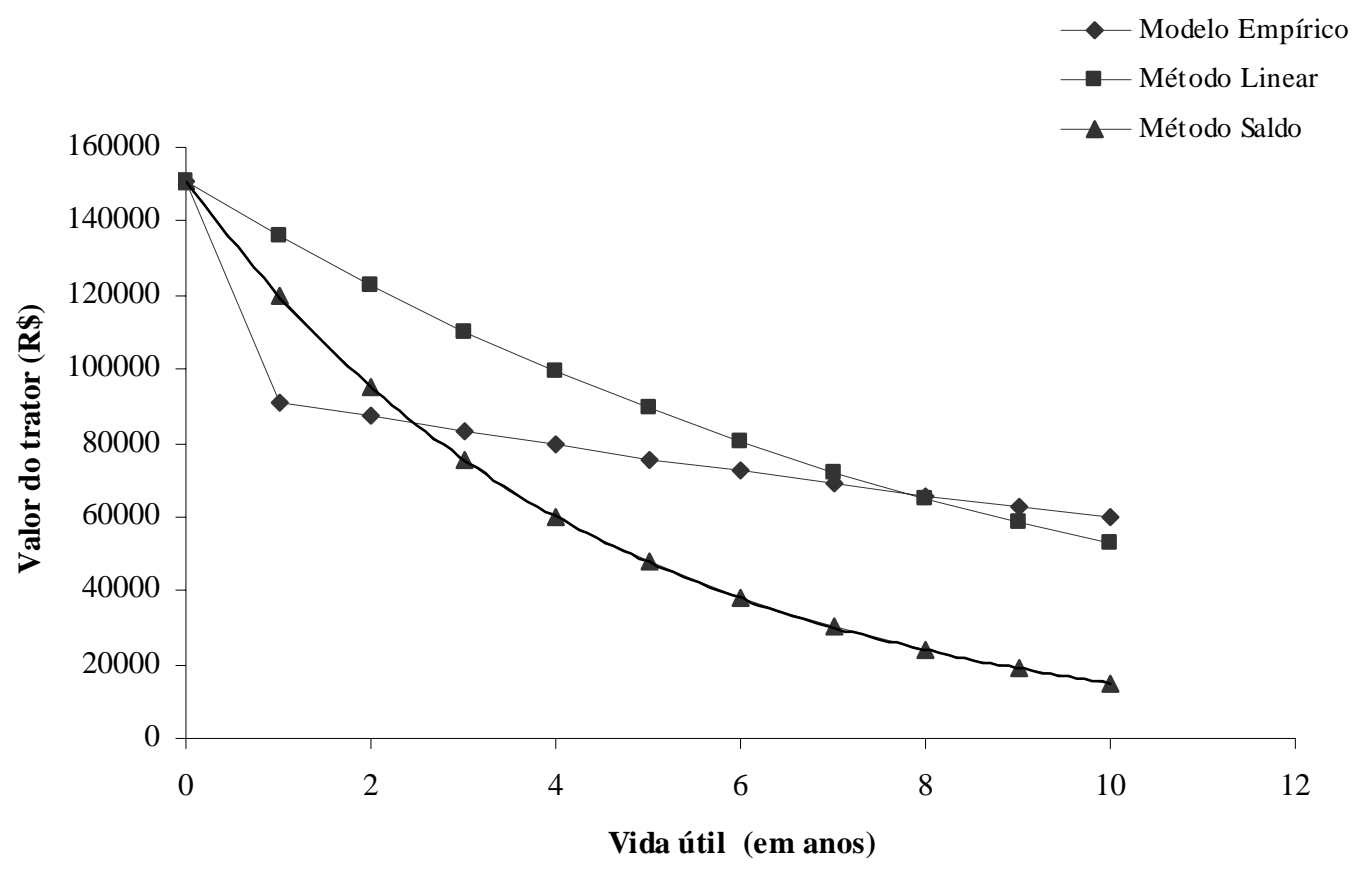




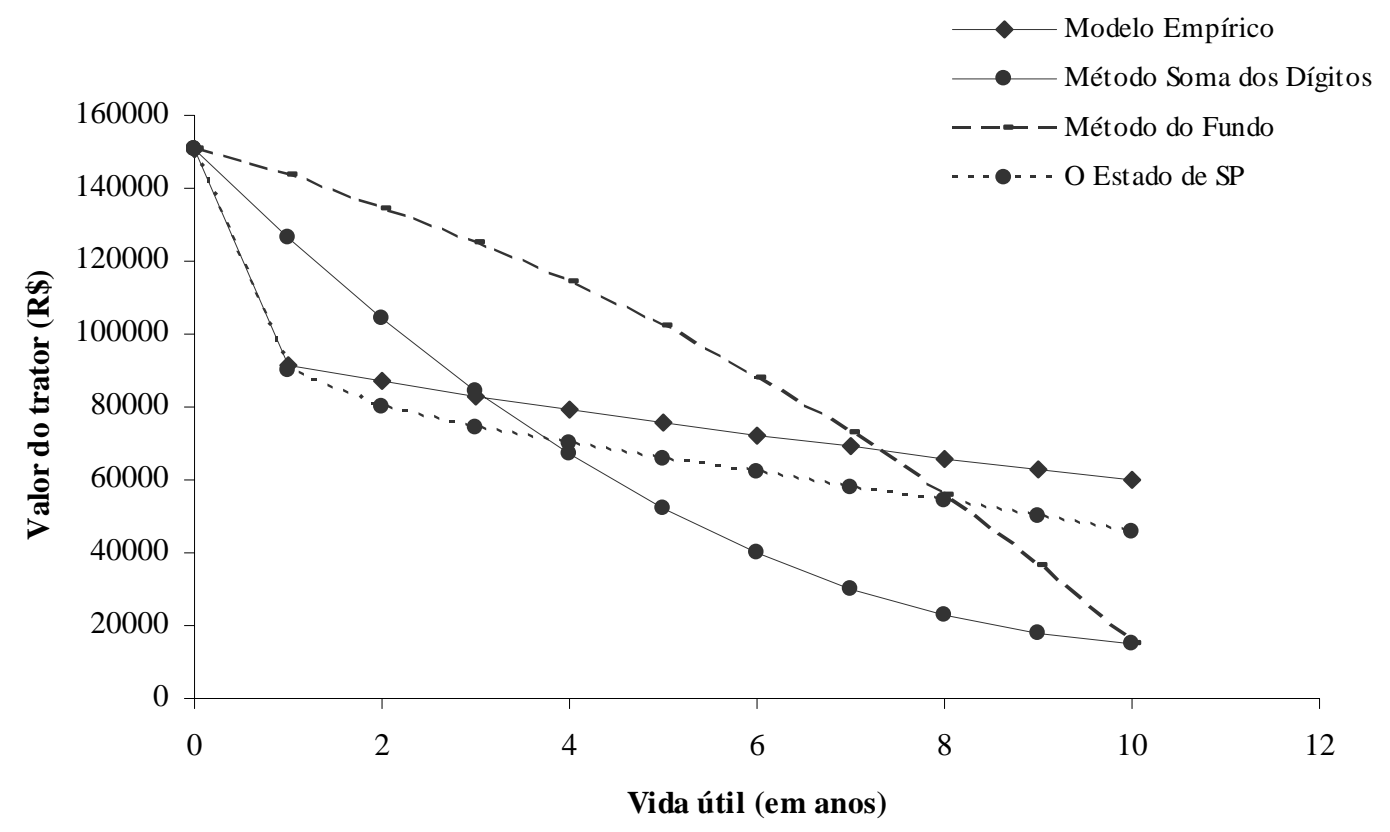

Figura 15 - Comparação com valores em reais de um trator Massey Ferguson MF 680 de 130,78 kW sem cabine

Na Figura 16 encontra-se uma simulação feita com o preço de um trator de 130.78 kW (MF 680) sem cabine. O modelo real mostra-se inicialmente com defasagem perante os outros modelos, mas torna-se preciso após 8 anos, em relação ao método fundo, soma e jornal Estado de S.Paulo. Em comparação com o método linear e saldo, o real supera o linear a partir do sétimo ano e saldo a partir do terceiro.

A comparação entre os valores obtidos com modelo empírico proposto neste trabalho e os valores da tabela de tratores usados do jornal O Estado de S.Paulo apresenta uma pequena diferença inicial no valor do trator com um ano de uso, porém esta defasagem se amplia consideravelmente ao fim do período de 10 anos. Cabe ressaltar que um percentual de $10 \%$ torna-se significativo na venda do trator usado. A discrepância entre os modelos que consideram os preços de mercado pode evidenciar a falta de organização do setor ou a diferenciação das amostras. 


\section{CONCLUSÕES}

Os resultados obtidos e as discussões realizadas permitiram concluir o que segue.

O questionário e a escala proposta para avaliar o estado de conservação dos itens que compõem os tratores agrícolas de roda mostraram-se válidos para serem adotados na avaliação da maquinaria.

O modelo empírico desenvolvido mostrou-se adequado para determinar o valor, em percentagem, de tratores agrícolas de roda durante sua vida útil, de 1 até 34 anos. A real depreciação de tratores de rodas no mercado assume uma redução de 37 \% do valor de aquisição no primeiro ano, seguindo-se uma queda constante ao longo da vida útil do trator.

O modelo empírico prediz, nessa amostra de tratores, o valor da maquinaria no mercado com maior confiabilidade que os demais modelos, incluindo-se o preço de tabela de tratores agrícolas de rodas usados publicado no jornal O Estado de S. Paulo. 
ANEXOS 
Anexo A - Relação das cidades visitadas nesta pesquisa, no raio de $150 \mathrm{~km}$ de Piracicaba

Araçoiaba da Serra

Araras

Capivari

Cerquilho

Engenheiro Coelho

Elias Fausto

Iracemápolis

Itu

Leme

Limeira

Piracicaba

Pirassununga

Ribeirão Preto

Rio das Pedras

Salto

Sorocaba

Tatuí

Tietê 
Anexo B - Fotos tiradas nas avaliações em campo sobre o estado de conservação de alguns itens

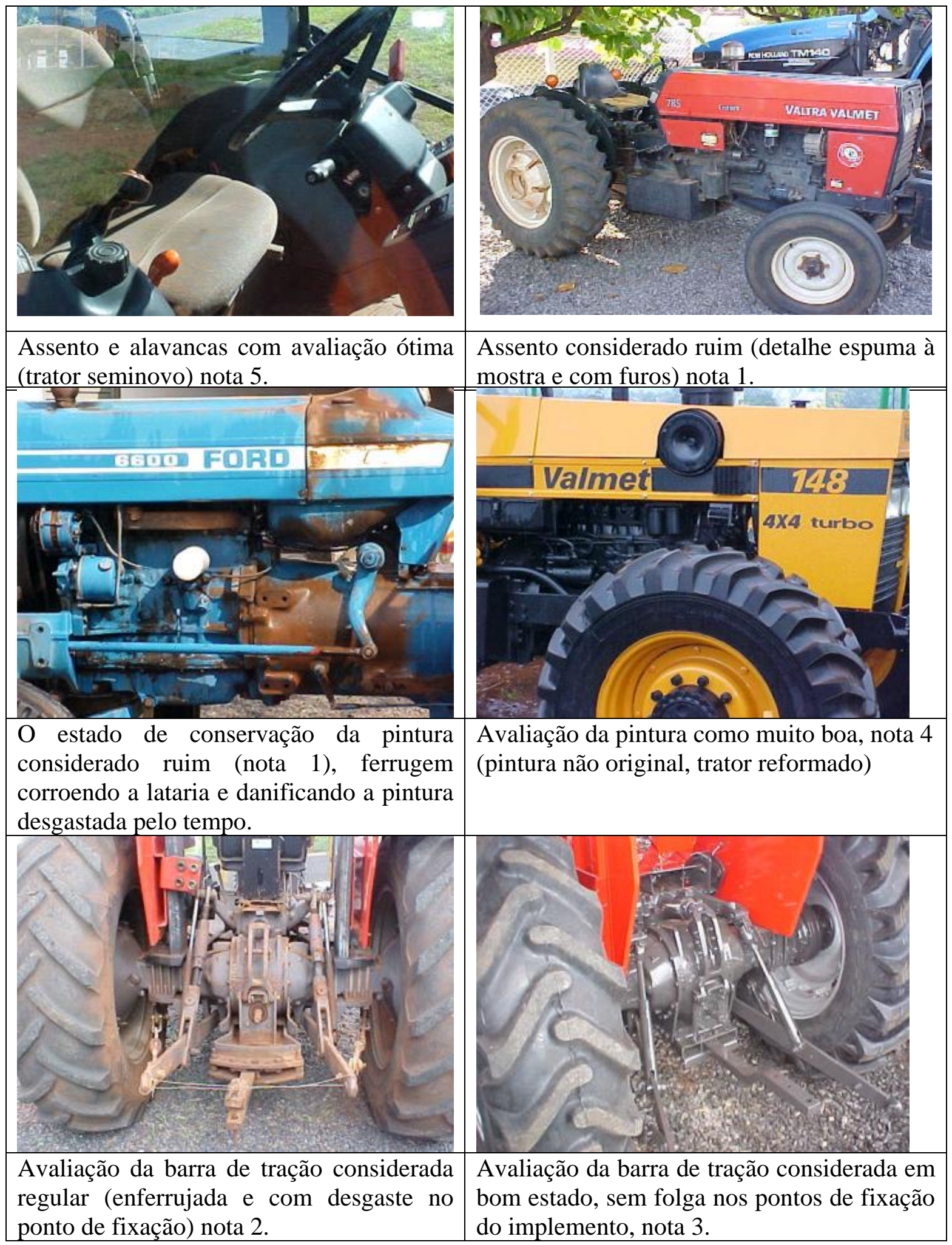


Anexo C - RELAÇÃO DE CONCESSIONÁRIAS (no raio 150Km)

AMICI TRATORES E MÁQUINAS AGRÍCS LTDA

Endereço: Rodovia Anhanguera, Sp 330, Km 171

Araras - SP

Telefone: 0xx19 35424700

HS TRATORES LTDA

Rua Otavio Melo , 192 centro

Araras SP

RIO CLARO AGRO DIESEL LTDA

Avenida 05, 238 - Centro

Rio Claro - SP

Telefone: 0 xx 19 524-2033

Rua Duque de Caixas, 1.034 - Centro

Pirassununga - SP

Telefone: 0 xx 19 561-4655

DINATRAC COMERCIAL E IMPORTADORA LTDA

Endereço: Av. Dr. Cássio Paschoal Padovani, 184

Piracicaba - SP

Telefone: 1934243611

SHARK TRATORES E PEÇAS LTDA.

Avenida Brasília, 1777 - Bairro Algodoal

Piracicaba - SP

Fone: 0 xx 193421.0024

TRATORTAG COMERCIO e REPRESENTACAO LTDA

Av Cássio Pascoal Padovani, 330 Bairro Morumbi

Piracicaba -SP CEP 13 420-015 
FORTRAC

Av Limeira 450 Bairro Vila Rezende

Piracicaba

SHARK TRATORES E PEÇAS LTDA.

Avenida Nove de Julho, 901 - Bairro Nossa Senhora Aparecida Itú - SP

Fone: 0 xx 114022.0970

APPENDINO MÁQUINAS AGRÍC. LTDA.

AV. DR. Octaviano Pereira Mendes, 263 Bairro Centro

Itu - SP

AUTOMEC COMERCIAL LTDA

Endereço: Av. Dom Aguirre, 2865

Sorocaba - SP

Telefone: 0xx15 2244188

EQUAGRIL EQUIPAMENTOS AGRÍCOLAS LTDA.

R:Bento Mascarenhas Jequitinhonha, 2455

Sorocaba - SP

IGARAPÉ DISTR. AGRÍC. COML. LTDA.

Sorocaba - SP

ROSSI TRATORES IMPLEMENTOS LTDA

Avenida Lacerda Franco, 145

Itatiba - SP

Telefone: 0 xx 114538.0326 
SHARK TRATORES E PEÇAS LTDA.

Rua Capitão Israel, 230 - Parque Industrial Jurumirim

Avaré - SP

Fone: 0 xx 143733.1188

AUTO IMPORTADORA PERES S.A.

Endereço: Av. João Osório, 411

São João da Boa Vista - SP

Telefone: 0xx19 6236311

G.R.A. MÁQUINAS AGRÍCOLAS E VEÍC LTDA

Endereço: Rua Domingos Zanin, 304

Araraquara - SP

Telefone: 0xx16 222.5655

COLORADO COMERCIO de MAQUINAS AGRICOLAS

Rod Washingtom Luiz Km 278

Araraquara-SP CEP 14 801-970

RACINE TRATORES

Estrada Vicinal Dr Celso Barbieri ,120 Pau Seco

Araraquara

COMPER TRATORES LTDA.

Avenida Presidente Vargas, 2714 - Bairro Quitandinha Araraquara - SP

Telefone: 0 xx 16222.4811

COMPER TRATORES LTDA.

Avenida Deputado Zien Nassif, 1944 - Distrito Industrial Jaú - SP

Fone: 0 xx 14622.4566 
MARKA LTDA

Av Deputado Zien Nassif , 560

Jaú - SP

SAMANJA e VERRUMA COM. de TRATORES e EQUI. AGR. LTDA

Av Netinho Prado , 1190 Vila Maria

Jaú - SP

TERRA TRATORES LTDA.

Endereço: Av. Lucio de Arruda Leme,1340

Jaú - SP

Telefone: 14 -36262120

IGARAPE - DISTR AGRICOLA e COMERCIAL LTDA

Rodovia SP 127 Km 113

Tatuí SP

SHARK TRATORES E PEÇAS LTDA

Avenida José de Almeida Carvalho, 1797 - Jd. Marabá

Itapetininga - SP

Telefone: 0 xx 153373.2860

TRATORTAG - COMERCIAL IMPORTADORA

Av José de Almeida carvalho, 2300 Vila Progresso

Itapetininga - SP CEP 18 200-000

ITADISTRAL

Rua 7 de setembro, 12A

Itapetininga

VALBRÁS TRATORES E PEÇAS LTDA

Av. Major José Levy Sobrinho, 1410

Bairro Boa Vista - Limeira - SP Telefone: 0 xx 19 3451-5105 
Anexo D - Página Principal do link www.esalq.usp.br/tratores

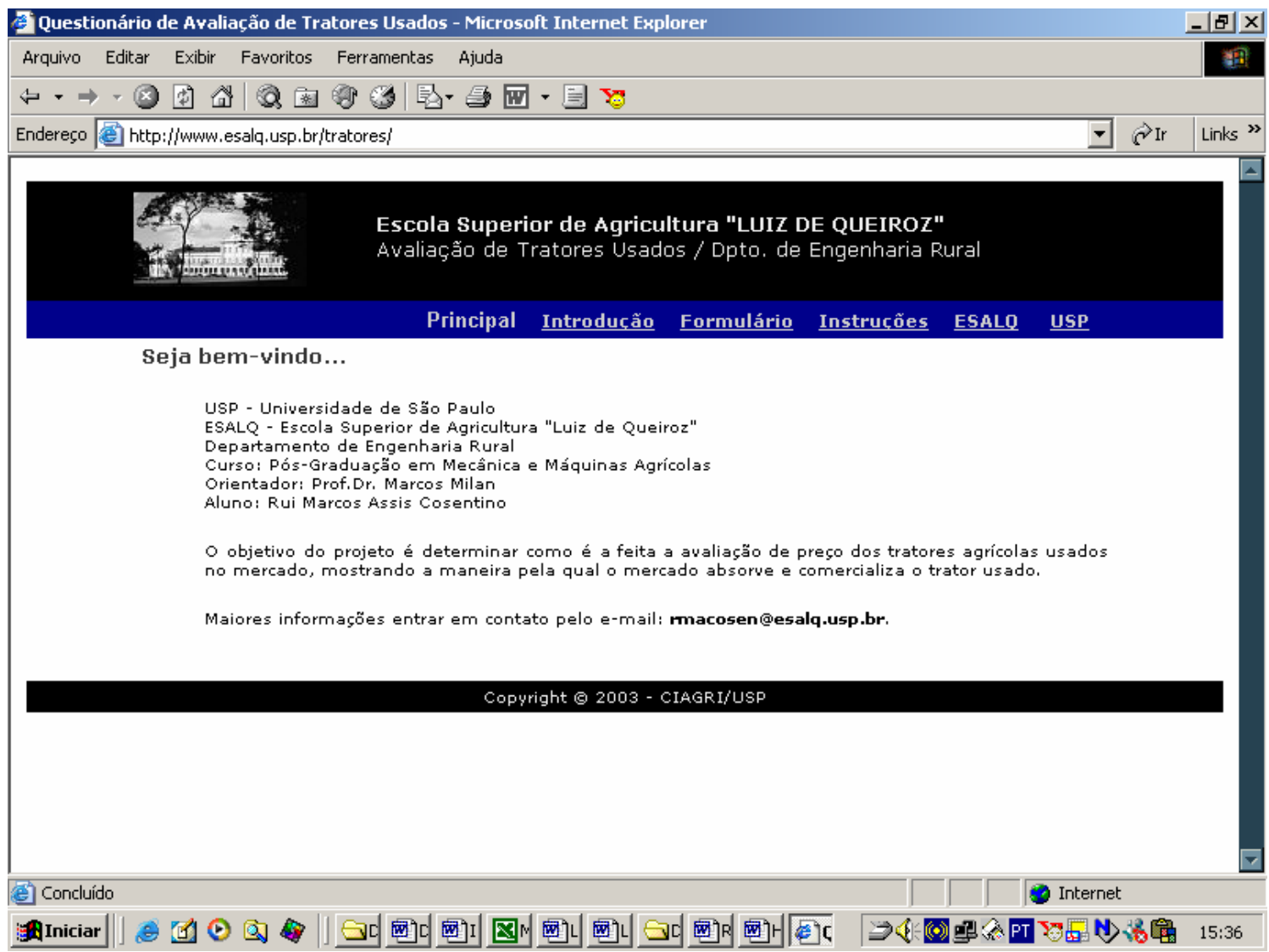


Anexo D - Página instruções para preenchimento do link www.esalq.usp.br/tratores

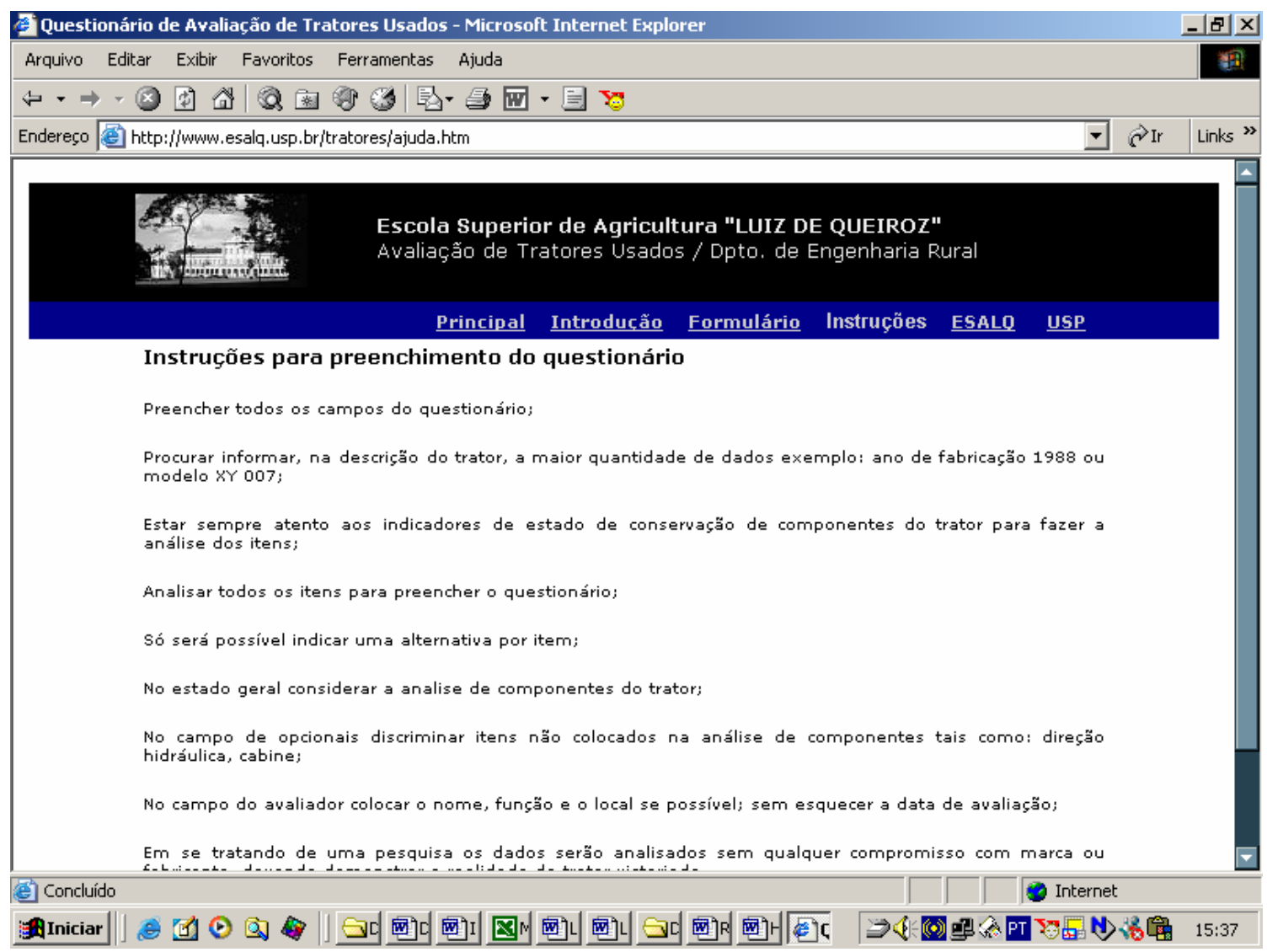


Anexo D - Página introdução do link www.esalq.usp.br/tratores

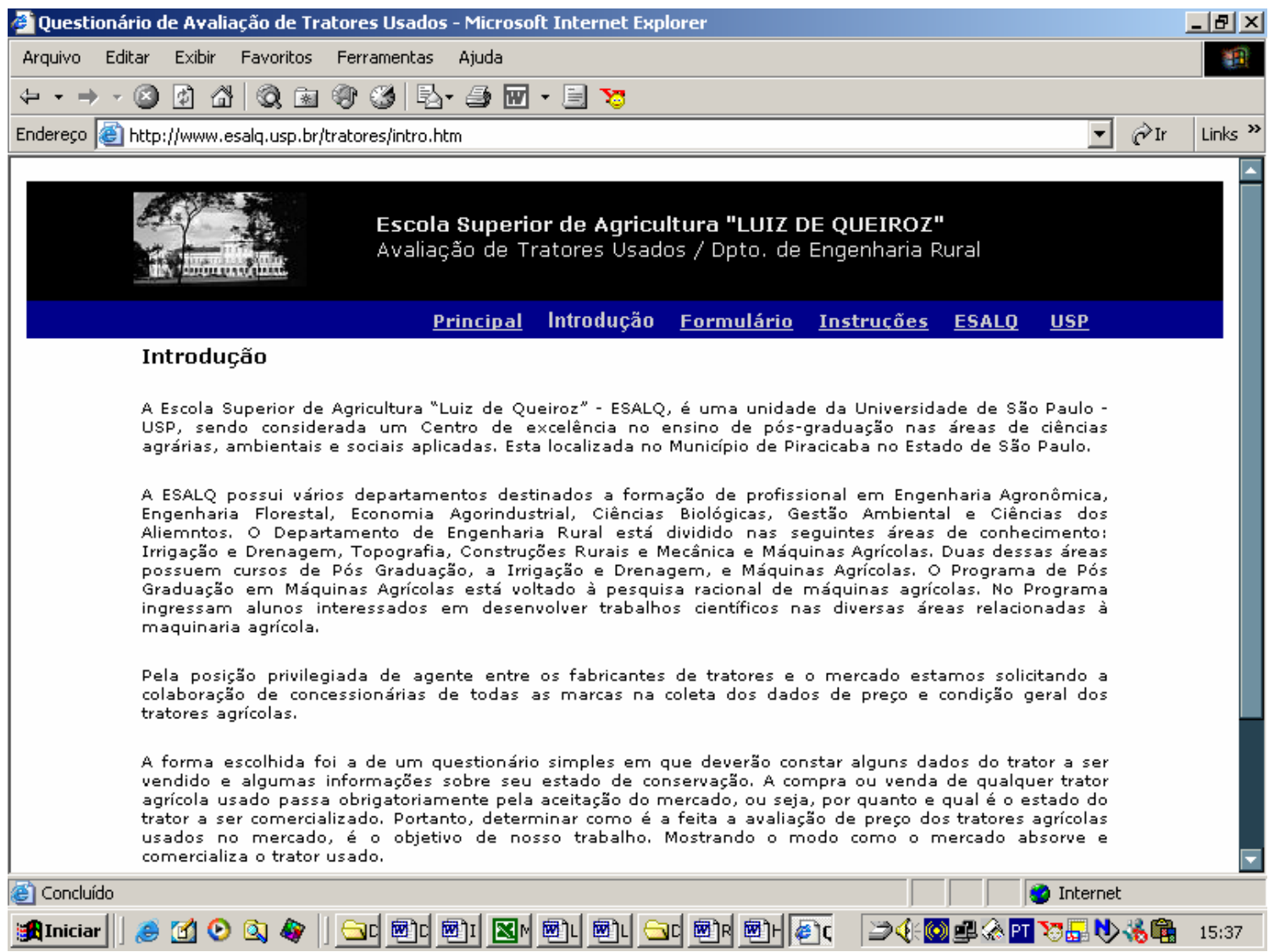


Anexo D - Página questionário do link www.esalq.usp.br/tratores

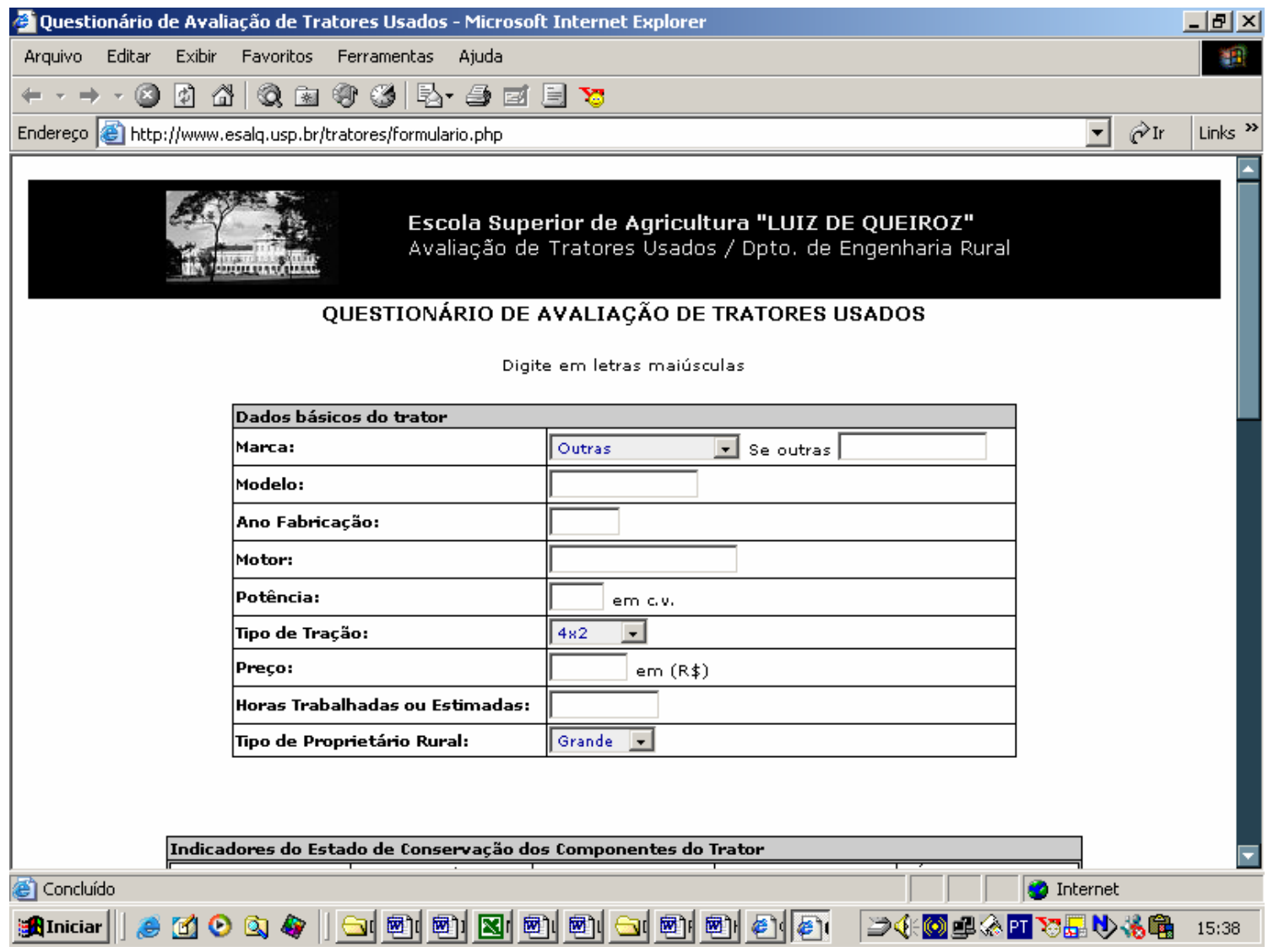




\section{Questionário de Avaliação de Tratores Usados}

Marca:

Modelo:

Ano de Fabricação:

Motor:

Potencia:

Tipo de Tração:

Horas trabalhadas ou estimadas:

Preço: Tipo de Proprietário Rural:

Indicadores do estado de Conservação dos Componentes do Trator

\section{Análise de Componentes}

Visual

Painel de Instrumentos Assento do Tratorista

Alavancas de Comando

Lataria

Pintura

Barra de Tração

Volante

\begin{tabular}{|l|l|l|l|l|}
\hline 1 & 2 & 3 & 4 & 5 \\
\hline 1 & 2 & 3 & 4 & 5 \\
\hline 1 & 2 & 3 & 4 & 5 \\
\hline 1 & 2 & 3 & 4 & 5 \\
\hline 1 & 2 & 3 & 4 & 5 \\
\hline 1 & 2 & 3 & 4 & 5 \\
\hline 1 & 2 & 3 & 4 & 5 \\
\hline
\end{tabular}

Correias

Tanque Combustível

Sistema de Injeção e Filtros

Purificador e Mangueiras

Radiador e Mangueiras

Carter

Vazamentos de Óleo

Coletor, Escape,Silencioso

Bomba d'Água

Ruídos do Motor

\section{Componentes Elétricos}

\begin{tabular}{|l|l|l|l|l|}
\hline 1 & 2 & 3 & 4 & 5 \\
\hline 1 & 2 & 3 & 4 & 5 \\
\hline 1 & 2 & 3 & 4 & 5 \\
\hline
\end{tabular}

Bateria

Cabos e Terminais

Faróis, Lanternas

Alternador

Motor de Partida

\begin{tabular}{|l|l|l|l|l|}
\hline 1 & 2 & 3 & 4 & 5 \\
\hline 1 & 2 & 3 & 4 & 5 \\
\hline 1 & 2 & 3 & 4 & 5 \\
\hline 1 & 2 & 3 & 4 & 5 \\
\hline 1 & 2 & 3 & 4 & 5 \\
\hline 1 & 2 & 3 & 4 & 5 \\
\hline 1 & 2 & 3 & 4 & 5 \\
\hline 1 & 2 & 3 & 4 & 5 \\
\hline 1 & 2 & 3 & 4 & 5 \\
\hline 1 & 2 & 3 & 4 & 5 \\
\hline
\end{tabular}

Embreagem

Caixa Câmbio

Diferencial

Tomada Potência

Freios

\begin{tabular}{|l|l|l|l|l|}
\hline 1 & 2 & 3 & 4 & 5 \\
\hline 1 & 2 & 3 & 4 & 5 \\
\hline 1 & 2 & 3 & 4 & 5 \\
\hline 1 & 2 & 3 & 4 & 5 \\
\hline 1 & 2 & 3 & 4 & 5 \\
\hline
\end{tabular}

\section{Pneus}

\begin{tabular}{|l|l|l|l|l|}
\hline 1 & 2 & 3 & 4 & 5 \\
\hline 1 & 2 & 3 & 4 & 5 \\
\hline 1 & 2 & 3 & 4 & 5 \\
\hline 1 & 2 & 3 & 4 & 5 \\
\hline 1 & 2 & 3 & 4 & 5 \\
\hline
\end{tabular}

Dianteiros

Traseiros

Eixo

Rodas

\begin{tabular}{|l|l|l|l|l|}
\hline 1 & 2 & 3 & 4 & 5 \\
\hline 1 & 2 & 3 & 4 & 5 \\
\hline 1 & 2 & 3 & 4 & 5 \\
\hline 1 & 2 & 3 & 4 & 5 \\
\hline
\end{tabular}

Estado Geral do Trator: Ruim (1) Regular (2) Bom (3) Muito Bom (4) Ótimo (5) Opcionais: Sim / Não Quais:

Avaliador:

Data da Avaliação:

\section{Local:}




\section{REFERÊNCIAS BIBLIOGRÁFICAS}

AMERICAN SOCIETY OF AGRICULTURAL ENGINEEERS. ASAE standards, 1999: standards engineering practices data. 46.ed. St. Joseph, 1999, 353-366: ASAE EP 496.2- Agricultural machinery management.

\section{ASSOCIAÇÃO NACIONAL DOS FABRICANTES DE VEICULOS}

AUTOMOTORES. Anuário Estatístico da Indústria Automobilística Brasileira2003. http://www.anfavea.com.br.(15/08/2003)

BALASTREIRE, L.A. Máquinas agrícolas.São Paulo: Manole, 1990. 307p.

BANCHI, A.D. Planejamento da utilização de uma frota de máquinas agrícolas em exploração policultural, determinando a solução de mínimo custo com auxílio de programação linear. Campinas, 1989. 214p. Dissertação (Mestrado)- Faculdade de Engenharia Agrícola, Universidade Estadual de Campinas.

BARGER, E.; LILJEDHAL, J.B.; CARLETON, J.B.; et al. Tratores e seus motores. Rio de Janeiro: Edgar Bluncher, 1966. 397p.

BARROS, A.L.M. de. Capital produtividade e crescimento da agricultura: o Brasil de 1970 a 1995. Piracicaba, 1999. 149p. Tese (Doutorado)- Escola Superior de Agricultura “Luiz de Queiroz”, Universidade de São Paulo. 
BARROS, G.S.C. Investimento em tratores agrícolas no Brasil. Piracicaba, 1980. 135p. Tese (Livre Docência) - Escola Superior de Agricultura “Luiz de Queiroz”, Universidade de São Paulo.

BURROWS, W.C.; SIEMENS, J.C. Determination of optimum machinery for corn soybean farms. Transaction of the ASAE, v.17, n.6, p.1130-1335, 1974.

BUSSAD, M. de O. Estratégias de marketing da industria de tratores agrícolas no Brasil: o caso da Massey Ferguson e da Valmet. São Paulo, 1997. 113p. Dissertação (Mestrado) - Escola de Administração de Empresas de São Paulo, Fundação Getulio Vargas.

CROSS, T.L.; PERRY, G.M. Depreciation patterns for agricultural machinery. American Journal of Agricultural Economics, v.77, p.194-204. fev. 1995.

CROSS, T.L.; PERRY, G.M. Remaining value functions for farm equipment. Transaction of the ASAE, v.12, n.5, p 547-553, 1996.

DUARTE, L.P.; MATTOS, Z.P.B.; NORONHA, J.F.; et al. Custos dos serviços de máquinas e implementos agrícolas. Piracicaba: ESALQ Departamento de Economia e Sociologia Rural, 1988. 32p.

DUMLER, T.J.; BURTON JUNIOR, R.O.; KASTEN, T. L. Predicting farm tractor values through alternative depreciation methods. Review of Agricultural Economics, v.25, n.2, p.506-522, 1998.

EDWARDS, W. Farm machinery selection. Machinery management, Iowa State University, 2001. 952 p. 
FRAUMENI, B.M. The measurement of depreciation in the U.S. national income and accounts, Survey of Current Business, v.1, p.7-23, jul. 1997.

FNP CONSULTORIA E COMÉRCIO. Agrianual 2003: anuário de agricultura brasileira. São Paulo, 2003. p.143-145: Mecanização Agrícola.

GRILICHES,Z. Capital stock in investment function: some problems of concept and measurement. In: CHIST et al. Measurement in Economics. Stanford: Stanford University Press, 1963.

HANSEN,L.; LEE, H. Estimating farm tractor depreciation: tax implications. Canadian Journal of Agricultural Economics, v.39, p.463-479. 1991.

HIRSCHFELD, H. Engenharia econômica e análise de custos. 5 ed. São Paulo: Atlas, 1992. 465p.

HOFFMANN, R.; SERRANO, O.; NEVES, E.M. et al. Administração da empresa agrícola. São Paulo: Pioneira, 1976. 323p.

HUNT,D.R. Farm power and machinery management. 6 ed., Iowa: Iowa State University Press, 1973. 324p.

INSTITUTO BRASILEIRO DE GEOGRAFIA E ESTATISTICA (IBGE) http://www.ibge.gov.br/. (18/09/2003)

INSTITUTO DE ECONOMIA AGRICOLA http://www.iea.sp.gov.br.(22/08/2003)

JORGENSON, W.D. Economy theory of replacement and depreciation. Investment. Cambridge: Mit Press, 1996. v.2. p.125-155. 
KASTEN, T. Farm machinery operation cost calculations. Kansas State University, 1997. 45p.

KLINGER, M.; MATTOS, Z.P. Custo-hora de tratores: um estudo preliminar. Economia Rural, v.2, n.25, p.75-89, abr./jun. 1987.

LEITE, H.P. Contabilidade para administradores. São Paulo: Atlas, 1993. 518p.

LOPES, J.D.S.; MANTOVANI, E.C.; PINTO, F.A.C.; QUEIROZ, D.M. de. Desenvolvimento de um programa computacional para selecionar economicamente, um sistema de mecanização agrícola. Pesquisa Agropecuária, v.30, n.4, p.537-542, abr. 1995.

MARCONI, M.A.; LAKATOS, E.M. Técnicas de pesquisa: planejamento e execução de pesquisas, amostragens e técnicas de pesquisa, elaboração, análise e interpretação de dados. 4 ed. São Paulo: Atlas, 1999. 260 p.

MARTIN, N.B.; SERRA, R. OLIVEIRA, M.D.M; et al.Sistema integrado de custos agropecuários - CUSTAGRI. Informações Econômicas, v.28, n.1, jan., 43 p, 1998.

MAYFELD,W.; HINES, G.S.; ROBERTS, L. A new method for estimating farm costs. Transaction of the ASAE, v.24, n.6, p 1446-1448, nov./dec. 1981.

MATTAR, F.N. Pesquisa de marketing, São Paulo: Atlas, 1993. 224p.

MATTAR, F.N. Pesquisa de marketing I, São Paulo: Atlas, 1996. 344p.

MIALHE, L.G. Manual de mecanização agrícola. São Paulo: Ceres, 1974.301p. 
MIALHE, L.G. Máquinas motoras na agricultura. São Paulo: EDUSP, 1980. V 1, 289p.

MIALHE, L.G. Máquinas Agrícolas: ensaios \& certificação. FEALQ. Piracicaba, SP. 1996. 772p.

MOLIN, J.P.; MILAN, M. Effect of globalization on the agricultural machinery industry in Brazil. Agricultural Mechanization in Asia, Africa and Latin America,. v.32, n.3, p.67-72, 2001.

MIRANI, A.N.; BUKHARI, S.B.; BALOCH, J.M. Unit cost of operation of farm tractors. Agricultural Mechanization in Asia, Africa and Latin America,. v.20, n.3, p.44-46, 1989.

MOLINA JUNIOR, W.F.; CANALE, A.C. Depreciação do trator agrícola no Brasil: valor corrente de mercado. Engenharia Agrícola, v.18, n.1, p.59-65, set.1998.

NOJIMOTO, T.; SIMON, E.J. O plano nacional da indústria de tratores agrícolas; uma análise. Revista de Economia Rural, v.24, n.4. p.393-401, out./dez. 1987.

NOJIMOTO, T. Utilização de tratores na agricultura. In: CONGRESSO BRASILEIRO DE ENGENHARIA AGRICOLA, 15; São Paulo, 1986. Resumos. Botucatu:, Sociedade Brasileira de Engenharia Agrícola, FCA-UNESP- Departamento de Engenharia Rural, 1986a. p.31.

NOJIMOTO, T. Utilização de tratores na agricultura. In: CONGRESSO BRASILEIRO DE ENGENHARIA AGRICOLA, 15, São Paulo, 1986. Resumos Botucatu: Sociedade Brasileira de Engenharia Agrícola, FCA-UNESP- Departamento de Engenharia Rural, 1986b. p.32. 
NORONHA, J.F. Projetos agropecuários: administração financeira, orçamento e viabilidade econômica. São Paulo: Atlas, 1981. 274p.

NORONHA, J.F.; MIALHE, L.G.; DUARTE, L.P. Custos dos sistemas tratorizados na agricultura brasileira. In: CONGRESSO BRASILEIRO DE ECONOMIA E SOCIOLOGIA RURAL, 29; Campinas, 1991. Anais Brasília: SOBER, 1991. p. 1333.

NOGUEIRA, A.C.L. Mecanização na agricultura brasileira: uma visão prospectiva. Caderno de Pesquisas em Administração, v.8, n.4, p.77-87, out./dez. 2001.

OLIVEIRA, M.D.M. Custo operacional e ponto de renovação de tratores agrícolas de pneus: avaliação de uma frota. Piracicaba, 2000. 150p. Dissertação (Mestrado)Escola Superior de agricultura “Luiz de Queiroz”, Universidade de São Paulo.

OLIVEIRA, M.D.M. Ponto de renovação de tratores agrícolas de pneus: avaliação de uma frota. Agricultura em São Paulo, v.48, n.1, p. 39-55, 2001a.

OLIVEIRA, M.D.M. Renovação de frota de tratores agrícolas de pneus: uma aplicação do método de custo anualizado equivalente. Informações Econômicas, v.31, n.11, 45 p, nov. 2001b.

PADOVEZE, C.L. Manual de contabilidade básica. 2.ed. São Paulo: Atlas, 1991. 294p.

PARMAR, R.S.; MCCLEDON, R.W.; POTTER, W.D. Farm machinery selection using and genetic algorithms. Transactions of ASAE, v. 39, n.5, p. 1905-1909, 1996. 
PERRY, G.M.; GLYER, J.D. Depreciation of durables assets: a reconciliation between hypotheses, Review of Economics and Statistics, v.72, p.524-529, 1990.

PERRY, G.M.; BAYANER,A.; NIXON, C.J.; The effect of usage and size on tractor depreciation, American Journal of Agricultural Economics, v.72, p.317-325. 1990.

PERREIRA, L.L. Um modelo empírico para o calculo dos custos na produção de feno. Piracicaba, 2003. 88p. Dissertação (Mestrado)- Escola Superior de Agricultura “Luiz de Queiroz”, Universidade de São Paulo.

REA, L.M.; PARKER, R.A. Designing and Conducting Survey Research: A Comprehensive Guide. New York: Jossey Bass. 1997. 262p.

REZENDE, J.L.P.; VALVERDE, S.R. Princípios de depreciação de máquinas e equipamentos. Revista Árvore, v.2, p.99-111, 1997.

RICHARDSON, A. J.; AMPT, E.S.; MEYBURG, A.H. Survey method for transport planning. Melboune: Eucalyptus Press, 1995. 291p.

ROCHA, S. Tratores agrícolas: um estudo dos determinantes da demanda interna. Revista Brasileira de Estatística, v.47, p 529-570, out-dez. 1986.

ROTZ, C.A.; MUHAR, H.A.; BLACK,J.R. Amultiple crop machinery selection algorithm. Transactions of the ASAE, v.26, n.3, p.1644-1649, 1983.

SAAD, A. Contribuição para avaliação de tratores agrícolas usados. Nova Granada Assistência Técnica da Associação Rural da Nova Granada, jul 1956, 8p. 
SALOMÃO, J.A.F. O MODERFROTA e a política de modernização da agricultura brasileira. Revista de Política Agrícola, v.12, n.1, p.15-21, jan/mar. 2003.

SILVA, C.R.L.; CARVALHO, M.A.; MARGARIDO, M.A. et al. O processo de modernização e o uso de tratores a agricultura brasileira. Agricultura em São Paulo, v.37, n.3, p 119-128.1990.

SOFFNER, R K. Gerenciamento global de sistema agrícola em unidades sucroalcooleiras através de programação linear. Stab. Açúcar, Álcool e Subprodutos Piracicaba, v.11, n.5 , p.16-20, mai.jun. 1993.

STULP, V.J.; MATTUELLA, J.L. Dimensionamento econômico d estoque de tratores para lavoura do arroz. Revista de Economia e Sociologia Rural, v.35, n.3. p.45-62, 1997.

TACHIBANA, A. Um modelo para avaliar sistemas mecanizados para aplicação de defensivos em culturas perenes. Piracicaba, 2000. 86p. Dissertação (Mestrado)Escola Superior de Agricultura “Luiz de Queiroz”, Universidade de São Paulo.

TACHIBANA, A.; MILAN, M. ; MOURÃO FILHO, F.A.A. Modelo para avaliar um sistema mecanizado para cultura do limão siciliano ( Citus limon, Brum.). Engenharia Agrícola, v.18, n.3, p. 34-43, 1999.

TEIXEIRA, L.F.G. desenvolvimento de uma equação para estimativa de custos de reparos e manutenção para tratores agrícolas de pneus. Piracicaba, 1995, 89p. Dissertação (Mestrado)- Escola Superior de agricultura "Luiz de Queiroz", Universidade de São Paulo. 
TURRA, F.E. Análise de diferentes métodos de cálculo de custos produção na agricultura brasileira. Piracicaba, 1990. 139p. Dissertação (Mestrado)- Escola Superior de Agricultura “Luiz de Queiroz”, Universidade de São Paulo.

WITNEY, B. Choosing \& using farm machinery. Scotland: Endhinburg: Landland Technology, 1988. 412p. 